San Jose State University

SJSU ScholarWorks

Faculty Publications, Biological Sciences

Biological Sciences

$1-1-2012$

\title{
Stressors and threats to the flora of Acadia National Park, Maine: Current knowledge, information gaps, and future directions
}

T B. Harris

WRA, Inc

N Rajakaruna

San Jose State University, nrajakaruna@gmail.com

\section{S J. Nelson}

Senator George J. Mitchell Center for Environmental and Watershed Research and Department of Plant, Soil and Environmental Sciences, University of Maine

P D. Vaux

Senator George J. Mitchell Center for Environmental and Watershed Research, University of Maine

Follow this and additional works at: https://scholarworks.sjsu.edu/biol_pub

Part of the Plant Sciences Commons

\section{Recommended Citation}

T B. Harris, N Rajakaruna, S J. Nelson, and P D. Vaux. "Stressors and threats to the flora of Acadia National Park, Maine: Current knowledge, information gaps, and future directions" Journal of the Torrey Botanical Society (2012): 323-344. https://doi.org/10.3159/TORREY-D-11-00086.1

This Article is brought to you for free and open access by the Biological Sciences at SJSU ScholarWorks. It has been accepted for inclusion in Faculty Publications, Biological Sciences by an authorized administrator of SJSU ScholarWorks. For more information, please contact scholarworks@sjsu.edu. 


\title{
Stressors and threats to the flora of Acadia National Park, Maine: Current knowledge, information gaps, and future directions ${ }^{1}$
}

\author{
Tanner B. Harris \\ WRA, Inc., 2169-G East Francisco Boulevard, San Rafael, CA 94901 \\ Nishanta Rajakaruna ${ }^{2}$ \\ College of the Atlantic, 105 Eden Street, Bar Harbor, ME 04069
}

Sarah J. Nelson

Senator George J. Mitchell Center for Environmental and Watershed Research and Department of Plant, Soil and Environmental Sciences, University of Maine, 5710 Norman Smith Hall, Orono, ME 04469

Peter D. Vaux

Senator George J. Mitchell Center for Environmental and Watershed Research, University of Maine, 5710 Norman Smith Hall, Orono, ME 04469

Harris, T. B. (WRA, Inc., 2169-G East Francisco Boulevard, San Rafael, CA 94901), N. RaJAKARunA (College of the Atlantic, 105 Eden Street, Bar Harbor, ME 04069), S. J. Nelson (Senator George J. Mitchell Center for Environmental and Watershed Research and Department of Plant, Soil and Environmental Sciences, University of Maine, 5710 Norman Smith Hall, Orono, ME 04469), AND P. D. VAux (Senator George J. Mitchell Center for Environmental and Watershed Research, University of Maine, 5710 Norman Smith Hall, Orono, ME 04469). Stressors and threats to the flora of Acadia National Park, Maine: Current knowledge, information gaps, and future directions. J. Torrey Bot. Soc. 139: 323-344. 2012.-Acadia National Park is a center of plant diversity in northeastern North America. The Park's varied habitats and flora are sensitive to a number of natural and anthropogenic perturbations. Stressors such as invasive plants, pest and pathogens, ozone, acidic fog and sulfur deposition, nitrogen deposition, heavy metals, fire and fire suppression, over-browsing, visitor use, hurricanes, and climate change have all had effects on the Park's habitats and plant species at some point and it is unclear how many of these stressors are currently affecting the flora of Acadia National Park. We discuss the botanical diversity of Acadia, assess the natural and anthropogenic stressors and threats affecting the Park's flora, and summarize critical information gaps to better assess the known stressors and threats to the flora. Understanding these stressors and threats is critical to making informed management decisions to preserve the botanical diversity of Acadia and other regional parks.

Key words: acidic fog, air pollution, climate change, conservation, exotic species, heavy metals, invasive species, mercury deposition, nitrogen deposition, ozone, pathogens, rarity, sulfur deposition.

Acadia National Park (ANP) preserves 19,178 hectares in Hancock and Knox counties along the coast of Maine in the northeastern

${ }^{1}$ We gratefully acknowledge financial support from North Atlantic Coast Cooperative Ecosystem Studies Unit, National Park Service, University of Maine, and College of the Atlantic. We thank Karen Anderson, Bruce Connery, Bill Gawley, Judy Hazen-Connery, David Manski, John McDade, Jim McKenna, Linda Gregory, and Geneva Langley of ANP for useful input and providing access to ANP's resources; Jill Weber for providing information on rare and invasive plants of ANP; Charlene Donohue of the Maine Forest Service for providing information on pests and pathogens; and Elizabeth Farnsworth, Anne Kozak, and two anonymous reviewers for feedback on the manuscript.

2 Author for correspondence: Email: nrajakaruna@, coa.edu

Received for publication November 21, 2011, and in revised form May 30, 2012.
United States (Fig. 1). It consists of land on Mount Desert Island (MDI) and portions of or entire nearby smaller islands, a portion of larger Isle au Haut (IAH) to the southwest of MDI, and the tip of the Schoodic Peninsula (SCH). The Park is located in a broad transition zone between southern deciduous and northern coniferous forests (Vaux et al. 2008). Sharp environmental gradients have produced diverse habitats harboring a wide range of species (Mittlehauser et al. 2010) and vegetation types (Gawler and Cutko 2010). Over a distance of only a few kilometers, elevations on MDI range from sea level to $466 \mathrm{~m}$ at the summit of Cadillac Mountain, with habitats rapidly transitioning from maritime to mountain summit. Similarly, rocky coastal bluffs with minimal soils occur within a few kilometers of inland bogs where peat is several meters thick. 

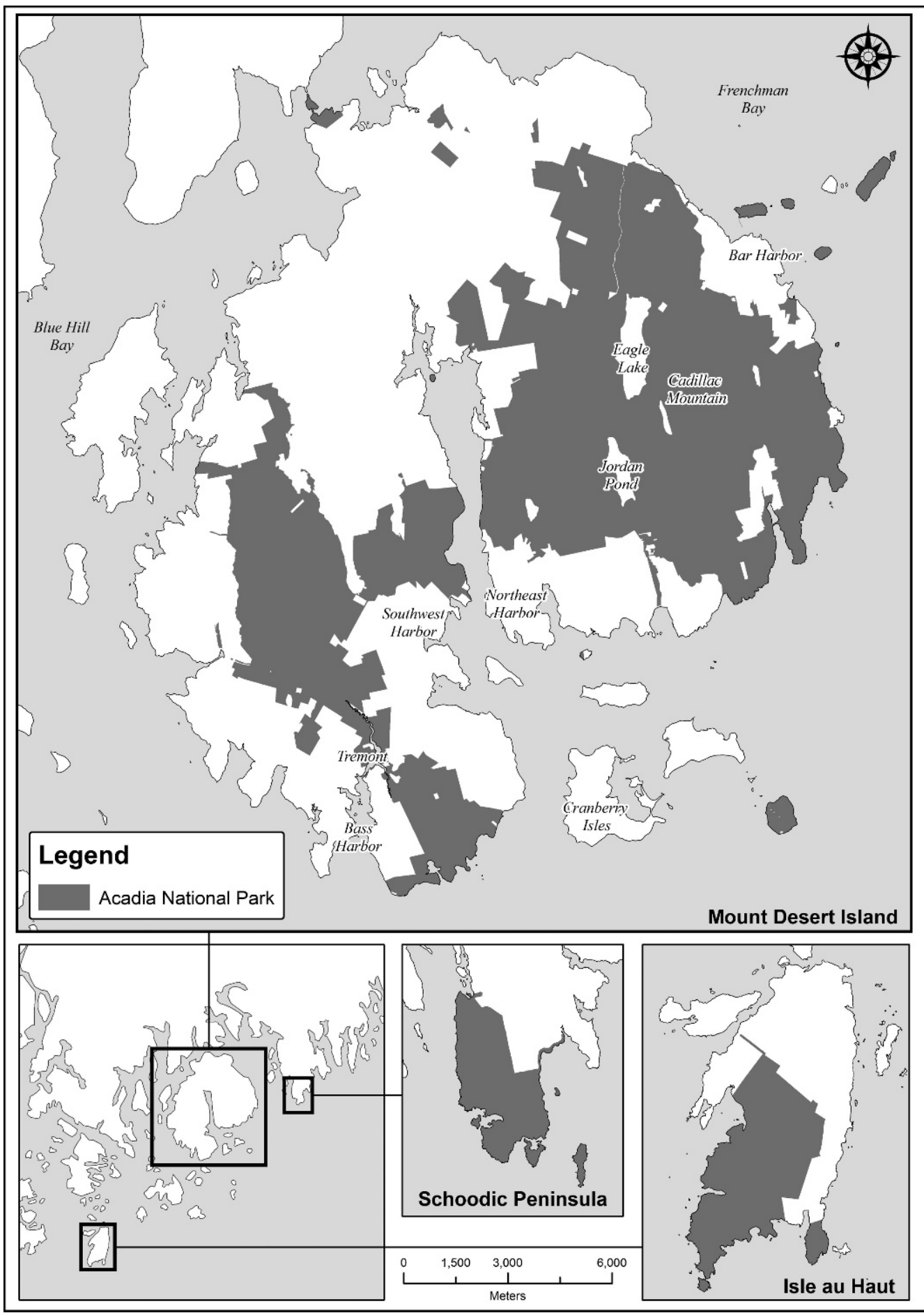

FIG. 1. The locations of MDI, SCH, and IAH units of ANP in coastal Maine. 
The Park's varied habitats and flora are sensitive to a number of natural and anthropogenic perturbations (Kahl et al. 2003, 2007, Vaux et al. 2008). Stressors such as invasive plants, pest and pathogens, ozone, acidic fog, sulfur deposition, nitrogen deposition, heavy metals, fire and fire suppression, over-browsing, visitor use, hurricanes, and climate change have all had effects on ANP's habitats and flora and are likely to influence the flora into the future. In this paper we discuss the major stressors and threats facing the flora of ANP from both natural and anthropogenic sources. We first discuss our current knowledge of the flora of ANP and identify areas in which more information is needed. We then discuss our knowledge of the major stressors and threats impacting the flora of ANP and identify critical gaps in research. Finally, we provide directions for future research. Our discussion is limited to the major known stressors and threats to the flora and to the direct and closely coupled indirect effects those stressors and threats pose to the flora. Loosely coupled indirect effects of stressors and threats are beyond the scope of this paper. Unless noted otherwise, plant nomenclature follows Haines (2011).

Current Knowledge of the Flora of Acadia National Park. The flora of ANP has been studied extensively for over a century (Rand and Redfield 1894, Wherry 1928, Stebbins 1929, Greene et al. 2005, Mittlehauser et al. 2010). Despite the extensive body of work aimed at cataloging the flora of ANP, a number of significant information gaps exist. Here we summarize our knowledge of the flora and identify areas in which additional research is needed.

VAscular Plants. Although ANP represents less than one percent of the Maine's land area, the Park harbors 1135 of the 2103 vascular plant taxa $(54 \%)$ listed for Maine (Campbell et al. 1995, Greene et al. 2005, Mittelhauser et al. 2010). Mount Desert Island is the most floristically diverse unit of ANP, supporting more than half of Maine's known vascular plant species (Campbell et al. 1995). Isle au Haut supports one-third of the vascular plant taxa listed for Maine. Existing knowledge of the SCH flora is limited; field surveys have been restricted to the southern third of the peninsula (Mittelhauser et al. 1996). Greene et al. (2005) concluded that the current vascular flora for the MDI unit of ANP is largely complete but that additional vegetation surveys are needed for the IAH and SCH units.

For virtually all plant groups, there is little information on trends in species composition or relative abundance. For example, over $20 \%$ of the vascular plants recorded for ANP are based on historic records and have not been documented in the area since 1980 (Greene et al. 2005). Understanding patterns of variation in the composition and relative abundance of species assemblages is critical to evaluating the status and trends of ANP's flora.

Species inventories of wetland and estuarine areas are relatively complete for ANP (Vaux et al. 2008) although there is limited knowledge of plants in Bass Harbor Marsh and Northeast Creek on MDI. Until recently, quantitative data on community composition and relative abundance at individual wetlands or for wetland classes have been limited. As part of the National Park Service's (NPS) Vital Signs Monitoring Program, the Northeast Temperate Network (NETN) has developed detailed freshwater wetland monitoring protocols (National Park Service 2006) that will produce reliable information on status and trends of wetland vegetation and water chemistry (Neckles et al. 2007). Acadia National Park also includes a large number of vernal pools, the floristic diversity of which has been largely unexamined (Ciccotelli et al. 2011). Improved documentation of vernal pool plants is needed to determine whether vernal pools harbor distinct species assemblages relative to the flora of permanent wetlands in ANP. Aquatic vascular plants were surveyed over a decade ago (Greene et al. 1999) and contemporary information is sparse, especially at IAH (Vaux et al. 2008).

Algae. Little is known about the marine algae at ANP, especially at IAH and other islands (Vaux et al. 2008). Ongoing surveys are developing information on marine algae at $\mathrm{SCH}$. Additional studies are required to document the diversity of freshwater algae throughout ANP.

Bryophytes And Lichens. Although the mosses of Maine have been intensely studied (Crum and Anderson 1981, Allen 2005, Allen and Pursell 2005, Miller 2006), the literature for bryophytes of ANP is restricted mostly to early studies consisting of partial species lists for MDI (Greenwood 1927a, b, Patterson 
1930, Schnooberger and Wynne 1941, Davis 1964a, b, Senter 1985) or more recent studies focusing on bryophytes of specific habitats or substrates on MDI (Cleavitt et al. 2009a, b). The lichen flora of ANP has received somewhat more attention (Wetmore 1984, Sullivan 1996, Bennett and Wetmore 2005, Cleavitt et al. 2009a). Bennett and Wetmore (2005) list 429 taxa of lichens for ANP, the fifth highest number of lichen species listed among 144 U.S. National Parks included in their study. The high diversity of lichens at ANP may result from the Park's proximity to the coast, its topographic heterogeneity, and management practices minimizing tree harvest (Cleavitt et al. 2009a). The macrolichen flora of ANP includes $63 \%$ of the species listed by Selva (1994) as indicators of old-growth, seven species listed as declining in New England, seven species listed as the rarest in New England (R1), and an additional 22 species listed as "rare and declining in New England" (Hinds and Hinds 2007). Additional surveys at the IAH and SCH units of ANP are needed to provide more comprehensive species lists for both bryophytes and lichens of ANP.

Rare and Endangered Plants. Rare and endangered plant species are well-documented in New England (Crow et al. 1981, Brumback et al. 1996, New England Wildflower Society 2010). Nearly 20\% (183 taxa) of vascular plants at ANP have been designated locally rare or state-listed; six species are globally rare (Brumback et al. 1996, Maine Natural Areas Program 2005a, Vaux et al. 2008). Greene et al. (2002) recommended developing a longterm plan for the conservation of all rare species at ANP. Although their effort helped to prioritize species and develop appropriate protocols for monitoring, little information is available on the status of rare plant populations in ANP. Table 1 identifies potential stressors and threats for rare plants at ANP for which such information is known (Greene et al. 2002, 2005, Vaux et al. 2008); however, such data are lacking for many rare plants in ANP. Further, there is little information on temporal trends in the status of individual populations of rare species. Potential stressors are often species-specific and include factors such as habitat loss, changes in hydrology, invasive and exotic species, visitor impacts, fire (or lack thereof), and erosion. Careful study of these rare plants will no doubt reveal addi- tional stressors as well as better approaches for their conservation. Given our limited understanding of the flora of IAH and $\mathrm{SCH}$, it is important that these areas be rigorously surveyed to document additional populations of rare or presumed extinct taxa as well as to document new taxa which may have gone unnoticed in previous surveys.

Natural Communities. In addition to containing more than $50 \%$ of Maine's vascular plant species, ANP also supports more than $50 \%$ of Maine's natural plant communities. Lubinski et al. (2003) recognized 53 floristic associations for ANP out of a total 104 such natural plant communities described for Maine (Gawler 2000, Gawler and Cutko 2010). These include 23 upland forest and woodland types, five wetland forest and woodland types, six non-forested upland types, six shrub or dwarf shrub wetland types, and 13 herbaceous wetland types. Spruce-Fir Forest is the most extensive vegetation type at ANP whereas the rarest are Dune Grassland, Pitch Pine-Corema Woodland, and Crowberry-Bayberry Headlands. Natural plant communities with high conservation value at ANP are listed in Table 2. Plant communities at IAH are not well documented.

Several species and communities in ANP are at the edge of their geographic range, making the study and preservation of those edge populations critical in terms of genetic diversity and species conservation (Greene et al. 2005, Thuiller et al. 2008). Notable in this regard are extant or historically documented taxa at or near either their southern range limit or their northern or eastern range limit (Table 3; Greene et al. 2002, 2005).

Stressors and Threats Affecting the Flora of Acadia National Park. Despite a large number of studies examining the effects of stressors on individual plants and natural communities in ANP, there are a number of significant information gaps. Here we discuss the anthropogenic and natural stressors and threats affecting the flora of ANP. We include in our discussion stressors and threats from invasive plants, pests and pathogens, ozone, acidic fog, nitrogen deposition, the deposition of mercury and other metals, fire (or lack thereof), browsing, visitor use, hurricanes, climate change, and the synergistic effects of multiple stressors. 


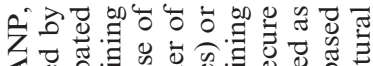

$\langle 0$

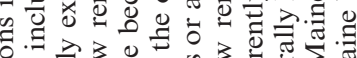

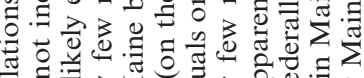

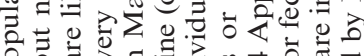

ڤั.

藏芯

苍令记

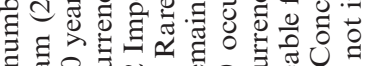

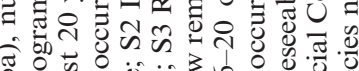

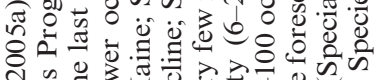

ते

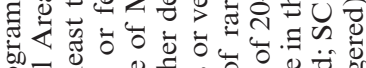

이요

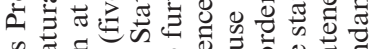

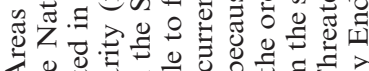

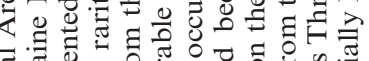

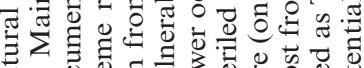

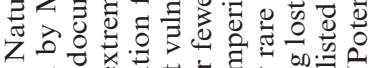

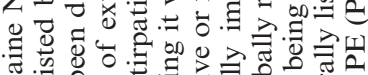

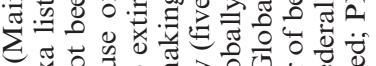

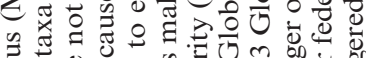

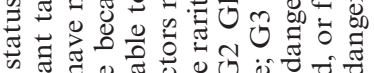

के जี

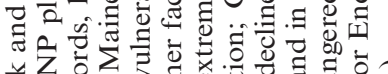

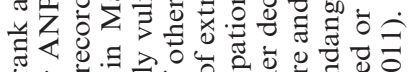

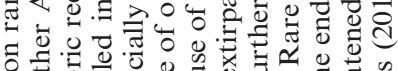

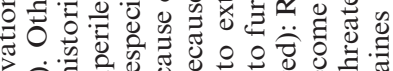

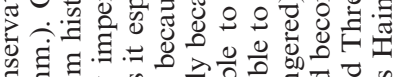

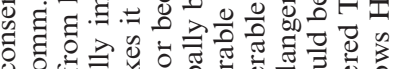

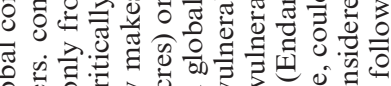

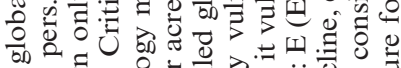

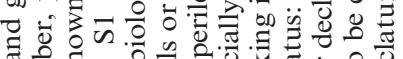

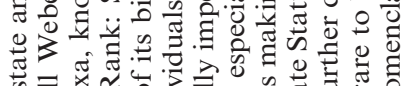

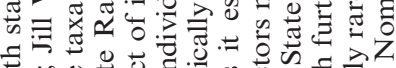

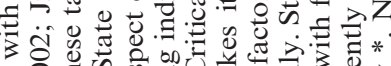

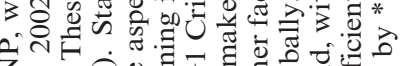

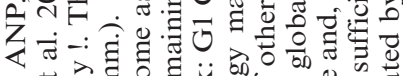

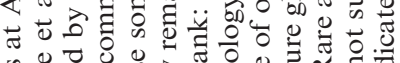

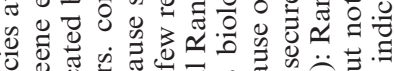

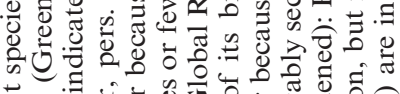

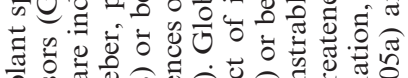

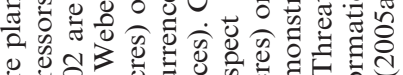

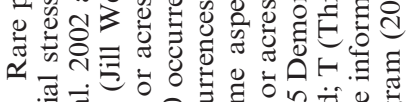

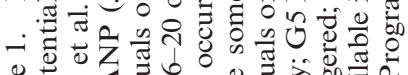

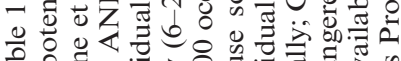

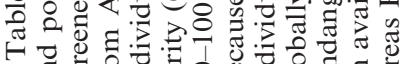

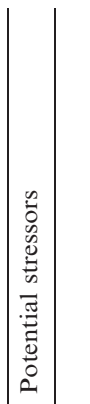

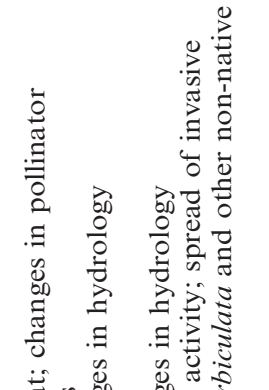

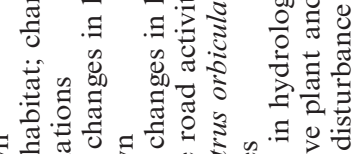

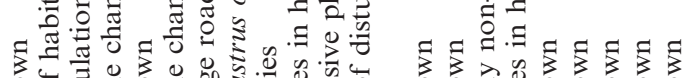

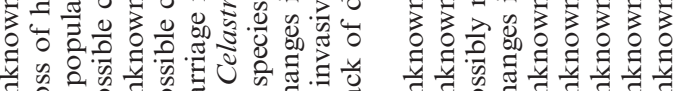

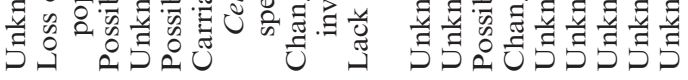

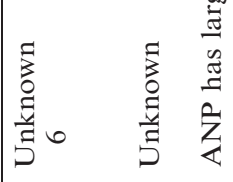

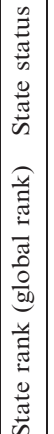

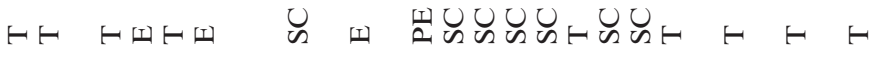

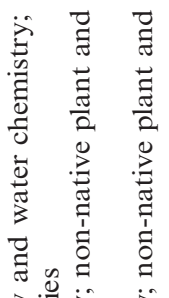

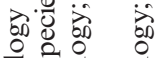

t⿹

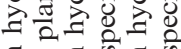
$\exists g . \Xi$ क क

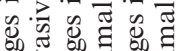

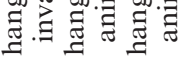

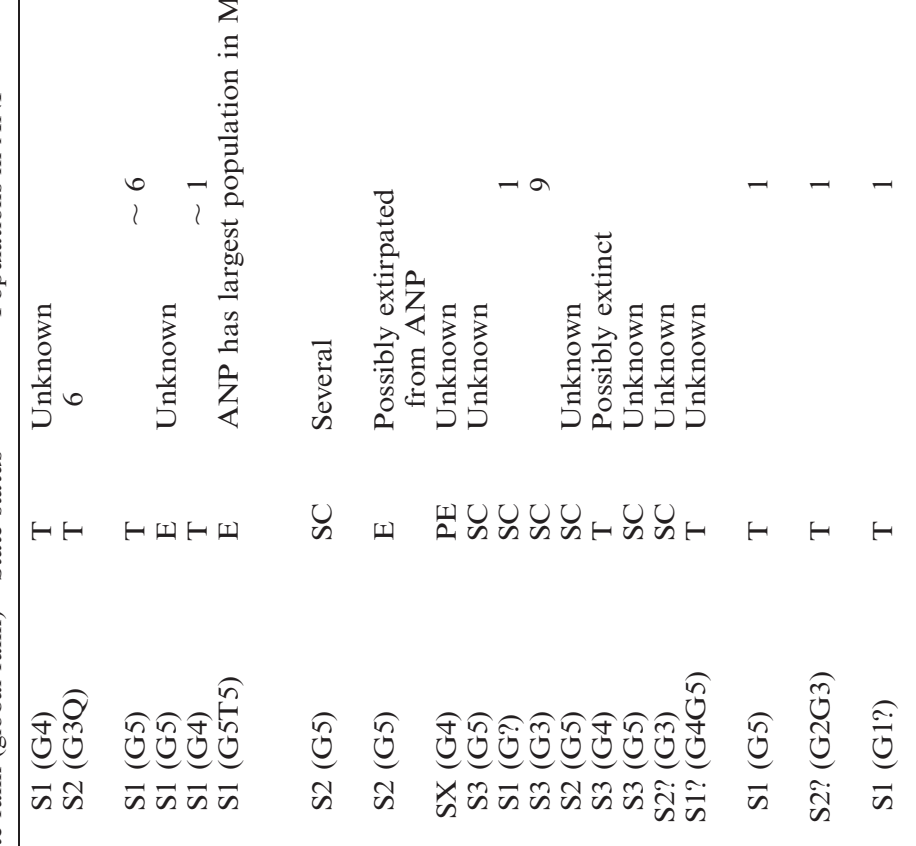

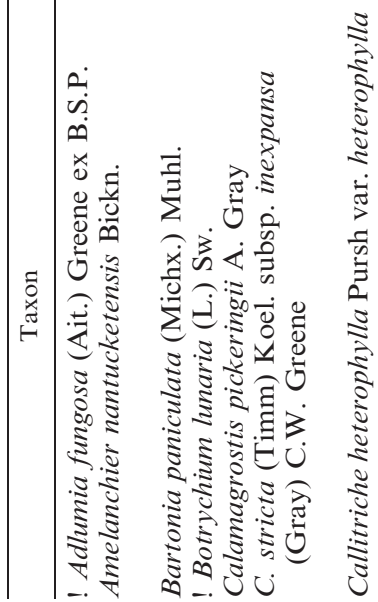
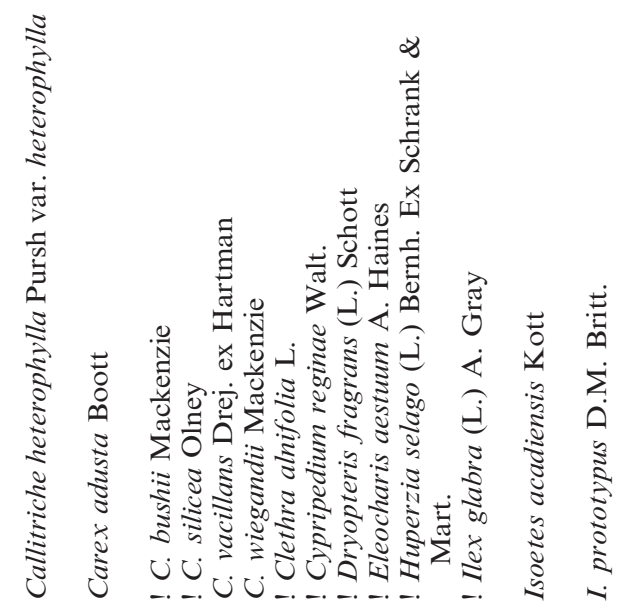


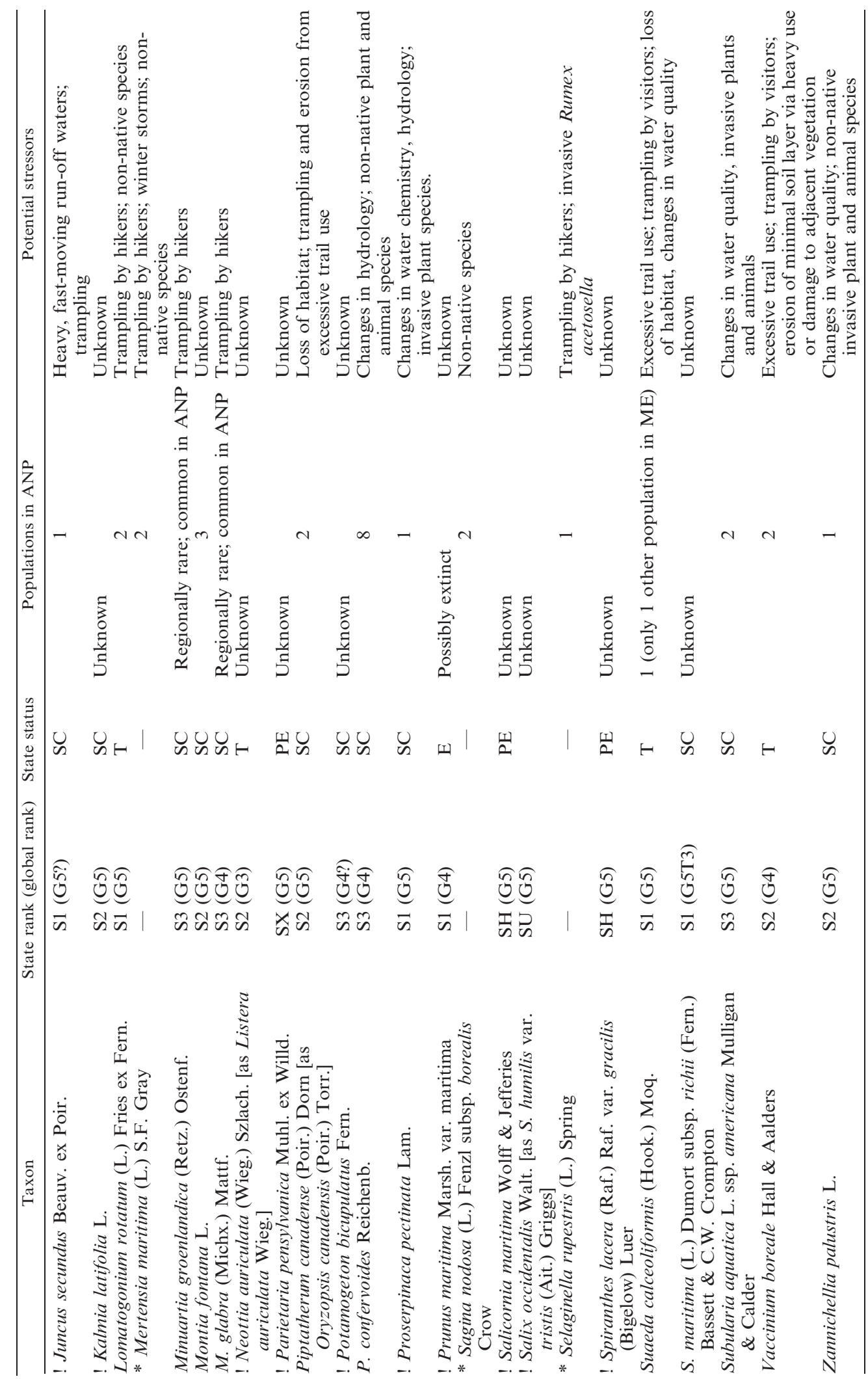


Table 2. Natural communities in ANP by unit (Lubinski et al. 2003), including state rarity ranking (State rank) by the Maine Natural Areas Program (2005c). State rank ranges from S1 (rare) to S5 (common).

\begin{tabular}{llc}
\hline \multicolumn{1}{c}{ Natural community type } & \multicolumn{1}{c}{ Locations } & $\begin{array}{c}\text { State } \\
\text { rank }\end{array}$ \\
\hline Dune Grassland & MDI & S2 \\
Pitch Pine-Corema Woodland & MDI, SCH & S3 \\
Crowberry-Bayberry Headlands & SCH & S3 \\
Coastal Plateau Bog Ecosystem & MDI & S3 \\
Raised Level Bog Ecosystem & MDI & S4 \\
Cinquefoil-Blueberry Low & MDI & S3 \\
$\quad$ Summit Bald & MDI & S4 \\
Maritime Spruce-Fir Forest & MDI & S3 \\
Pitch Pine Woodland & MDI & S3 \\
Red Pine Woodland & MDI & S4 \\
Spruce-Pine Woodland & MDI & S4 \\
Spruce-Northern Hardwood & & \\
$\quad$ Forest & MDI & S4 \\
Streamshore Ecosystem & MDI & S2 \\
White Cedar Woodland & MDI, SCH & S3 \\
Jack Pine Woodland & SCH & S3 \\
Downeast Maritime Shrubland & SCH & S4 \\
Open Headland & & \\
\hline
\end{tabular}

Invasive Plants. Invasive species are often considered a direct cause of the loss of biodiversity worldwide (Didham et al. 2005). Twenty five percent of ANP's plant taxa are considered exotic in Maine (Greene et al. 2005) compared to $30 \%$ statewide (Campbell et al. 1995). Invasive or potentially invasive plant species in ANP along with their extent of distribution within the Park, level of potential ecological impact, and ease of control are listed in Table 4. Most of these taxa occur on MDI and were likely intentionally introduced (Greene et al. 2005). Alliaria petiolata (M.Bieb) Cavara \& Grande is a more recently-introduced aggressive invasive and was likely unintentionally introduced (Greene et al. 2005). Invasive species are more abundant on the eastern side of MDI (Fig. 2; Greene et al. 2005, Vaux et al. 2008, Weber and Rooney 2007).

Potentially invasive species such as Hypericum prolificum L. and Physocarpus opulifolius (L.) Maxim, although native to central and eastern North America, are in Maine only as garden escapees (Haines and Vining 1998, Greene et al. 2005). These species as well as Luzula luzuloides(Lam.) Dandy \& Wilmot., another potentially invasive species (Greene et al. 2005), are all found in small numbers adjacent to basin wetlands on the MDI unit of ANP, mostly within the areas burned during the 1947 fire (Greene et al. 2005). Lythrum
Table 3. Species occurring in ANP at or near their southern or their northern or eastern range limit. Nomenclature follows Haines (2011).

\begin{tabular}{ll}
\hline \multicolumn{1}{c}{ Species } & Range Limit at ANP \\
\hline $\begin{array}{l}\text { Clethra alnifolia } \text { L. } \\
\text { Decodon verticillatus (L.) Ell. }\end{array}$ & $\begin{array}{l}\text { Northern or Eastern } \\
\text { Northern or Eastern }\end{array}$ \\
$\begin{array}{l}\text { Iris hookeri Penny ex D. Don } \text { Secundus } \text { Beauv. ex } \\
\text { Pouthern }\end{array}$ & Northern or Eastern \\
Kalmia latifolia L. & Northern or Eastern \\
Lomatogonium rotatum (L.) & Southern \\
Fries ex Fern. & \\
$\begin{array}{l}\text { Montia fontana } \text { L. } \\
\text { Pinus rigida } \text { P. Mill }\end{array}$ & Southern \\
$\begin{array}{l}\text { Prunus } \text { maritima } \text { Marsh. var. } \\
\text { maritima }\end{array}$ & Northern or Eastern \\
$\begin{array}{l}\text { Quercus } \text { ilicifolia } \text { Wangenh. } \\
\text { Rhodiola rosea } \text { L. }\end{array}$ & Northern or Eastern \\
Rubus chamaemorus L. & Southern \\
Rubus odoratus L. & Southern \\
& Northern or Eastern
\end{tabular}

salicaria $\mathrm{L}$. has, to date, only been recorded from the MDI unit of ANP. Its spread has been controlled through a Park management program since 1988 (Chase et al. 2002). Exotic, invasive species are considered a potentially significant stressor for a number of rare plant species in ANP (Table 1; Greene et al. 2004).

Reiner and McLendon (2002) evaluated exotic species that threaten ANP and described management protocols for each species. They estimated potential effects of exotic species on native plant communities within ANP, ranked exotic species based on their potential impacts on native plant species and their communities, and developed management protocols to maintain exotic species at levels that protect native plant communities. Their final assessment identified 16 species of concern in ANP and recommended eight species for highest management priorities. Greene et al. (2004) documented the distribution and abundance of 24 invasive species in ANP, including 11 exotic species from the previous study by Reiner and McLendon (2002) and 13 new species. Berberis thunbergii DC., non-native Lonicera taxa, and Frangula alnus Mill. occurred at more sites than all other invasive species at ANP and were concentrated around Great Meadow and Sieur de Monts Spring on the eastern side of MDI. Greene et al. (2004) suggested that the best strategy for management of invasive species at ANP is by site rather than by species because many of the species are limited to only a few localities where they co-occur with a number of other invasive species. 
Table 4. Plant species considered invasive or potentially invasive in ANP including the Park unit in which the species is found, extent of distribution within ANP, level of potential ecological impact, and ease of control (Reiner and McLendon 2002, Greene et al. 2004, 2005, Weber and Rooney 2007). For some species, such information is not available. Species also considered to be invasive elsewhere in Maine (Maine Natural Areas Program 2005b) are indicated by *. Species currently occurring within and in close proximity to the Park and considered problematic by the National Park Service (2007a) are indicated by $\wedge$. Nomenclature follows Haines (2011).

\begin{tabular}{|c|c|c|c|c|c|}
\hline & Species & ANP Unit & Distribution & $\begin{array}{l}\text { POtential } \\
\text { impact }\end{array}$ & $\begin{array}{l}\text { Ease of } \\
\text { control }\end{array}$ \\
\hline & Acer ginnala Maxim. & MDI, IAH & Narrow & Minor & Easy \\
\hline$\wedge$ & A. platanoides $\mathrm{L}$. & MDI, IAH & Narrow & Serious & Easy \\
\hline \multirow[t]{2}{*}{$* \wedge$} & Alliaria petiolata (Bieb.) Cavara \& Grande & MDI & Wide & Serious & Difficult \\
\hline & Aruncus dioicus (Walt.) Fern. var. dioicus & MDI & - & - & - \\
\hline$\wedge$ & Berberis $x$ ottawensis Schneid. & MDI & Narrow & Minor & Easy \\
\hline \multirow[t]{2}{*}{$* \wedge$} & B. thunbergii DC. & MDI, IAH & Wide & Serious & Difficult \\
\hline & B. vulgaris $\mathrm{L}$. & MDI & Narrow & Minor & Easy \\
\hline \multirow[t]{2}{*}{$\wedge$} & Bromus inermis Leyss. & MDI & Narrow & Minor & Difficult \\
\hline & Cardamine impatiens L. & MDI & Narrow & Serious & Easy \\
\hline$* \wedge$ & Celastrus orbiculatus Thunb. & MDI, IAH & Wide & Serious & Difficult \\
\hline$\wedge$ & Cirsium arvense (L.) Scop. & MDI, IAH, SCH & Wide & Minor & Difficult \\
\hline$\wedge$ & Dactylis glomerata $\mathrm{L}$. & MDI, IAH, SCH & Wide & Minor & Difficult \\
\hline$\wedge$ & Euonymus alatus (Thunb.) Siebold & MDI & Narrow & Serious & Easy \\
\hline$*$ & Fallopia japonica (Houtt.) Denr. & MDI, IAH & Narrow & Serious & Difficult \\
\hline \multirow[t]{5}{*}{$* \wedge$} & Frangula alnus P. Mill. & MDI & Narrow & Serious & Difficult \\
\hline & Hypericum prolificum $\mathrm{L}$. & MDI & Narrow & Serious & Easy \\
\hline & $\begin{array}{l}\text { Ligustrum obtusifolium obtusifolium Sieb. } \\
\text { \& Zucc. var. suave (Kitagawa) H. Hara } \\
\text { (as L. amurense Carr.) }\end{array}$ & IAH & Narrow & Minor & Easy \\
\hline & L. vulgare $\mathrm{L}$. & MDI & Narrow & Minor & Easy \\
\hline & Lonicera japonica Thunb. & MDI & Narrow & Serious & Easy \\
\hline$\wedge$ & L. $x$ bella Zabel & MDI & Narrow & Serious & Easy \\
\hline \multirow[t]{3}{*}{$* \wedge$} & L. morrowii Gray & MDI, SCH & Wide & Serious & Easy \\
\hline & Lupinus polyphyllus Lindl. var. polyphyllus & MDI, IAH & Narrow & Serious & Easy \\
\hline & $\begin{array}{l}\text { Luzula luzuloides (Lam.) Dandy \& Wilmott } \\
\text { ssp. luzuloides }\end{array}$ & MDI & Narrow & Serious & Easy \\
\hline \multirow[t]{4}{*}{$* \wedge$} & Lythrum salicaria $\mathrm{L}$. & MDI & Narrow & Serious & Difficult \\
\hline & Physocarpus opulifolius (L.) Maxim. & MDI & Narrow & Minor & Easy \\
\hline & Poa nemoralis L. & MDI & - & - & - \\
\hline & Robinia pseudoacacia $\mathrm{L}$. & MDI & Narrow & Minor & Easy \\
\hline$* \wedge$ & Rosa multiflora Thunb. ex Murr. & MDI, SCH & Narrow & Serious & Easy \\
\hline$\wedge$ & Solanum dulcamara L. var. dulcamara & MDI, IAH, SCH & Wide & Minor & Difficult \\
\hline \multirow[t]{2}{*}{$\wedge$} & Sonchus arvensis L. & MDI, IAH, SCH & Narrow & Minor & Difficult \\
\hline & Symphoricarpos albus (L.) Blake & MDI, IAH & - & - & - \\
\hline \multirow[t]{2}{*}{$\wedge$} & Tussilago farfara $\mathrm{L}$. & MDI & Wide & Minor & Easy \\
\hline & Vicia cracca L. ssp. cracca & MDI, IAH, SCH & - & - & - \\
\hline
\end{tabular}

There are currently no known invasive exotic freshwater plants in the ANP region (Greene et al. 2005, Vaux et al. 2008); Greene et al. (1999) recorded only one non-native aquatic species for MDI, Nymphaea tuberosa as Nymphaea odorata subsp. tuberosa. It had been found at MDI's Little Long Pond in Seal Harbor and there was no evidence of spread to other water bodies on MDI.

There is a need to better evaluate which exotic species represent threats to ANP's native flora and habitats and what the competitive mechanisms are for each aggressively invasive species. Rapid assessments for invasive species, such as those conducted by Weber and Rooney
(2007), may provide a potentially valuable tool for detecting exotic species-related problems at ANP; however, detailed species-level studies are needed to develop effective management practices. Attention should also be given to aquatic invasive species to determine whether those present elsewhere in Maine are appearing in the freshwater ponds and lakes at ANP (Maine Department of Environmental Protection 2005) and to develop effective strategies to prevent their spread.

Pests and Pathogens. Pests and pathogens are a serious threat to native plants and their ecosystems (Torchin and Mitchell 2004) and 


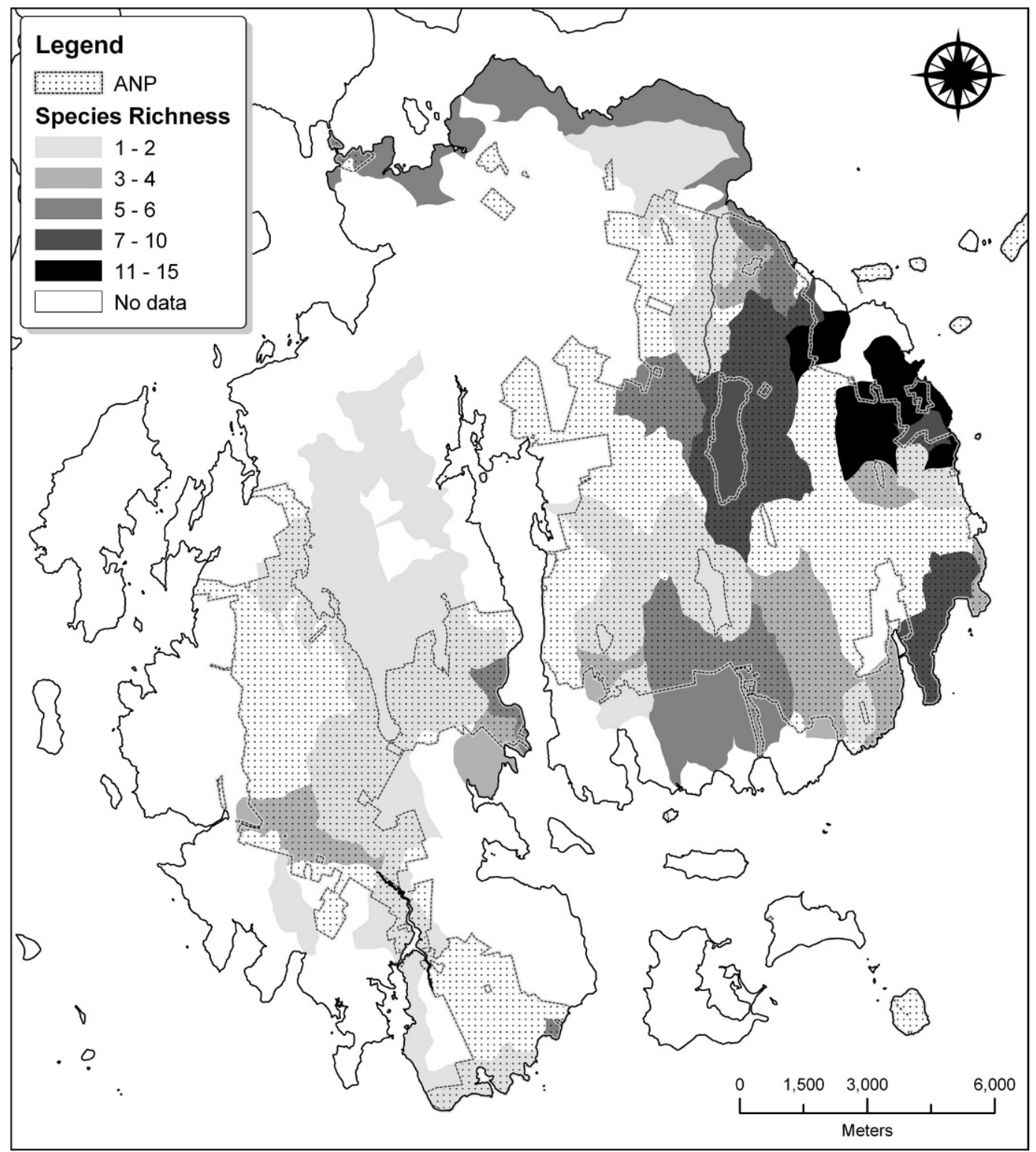

FIG. 2. Distribution and species richness of invasive plant species by watershed on the MDI unit of ANP (Greene et al. 2004).

could have detrimental short- and long-term effects on plant species in ANP. In addition to species-level effects, pests and pathogens can have impacts on ecosystem processes such as productivity, nutrient cycling, and food webs (van der Putten et al. 2007). Pests and pathogens are likely to influence plant species transitions at ANP over the next few decades (Bailo et al. 2004, Small et al. 2005, Lovett et al. 2006), a problem expected to be exacerbated by global climate change (Dukes et al.
2009). Pests and pathogens posing current or immediate threats to ANP's plants are listed in Table 5. Regular monitoring of these taxa is needed as their host plants are abundant at ANP.

Pests and pathogens that pose a particular threat to the flora of ANP include the insects Hemlock Wooly Adelgid, Elongate Hemlock Scale, Asian Longhorned Beetle, Emerald Ash-borer, and the pathogen Phytophthora ramorum. Although these species have not 


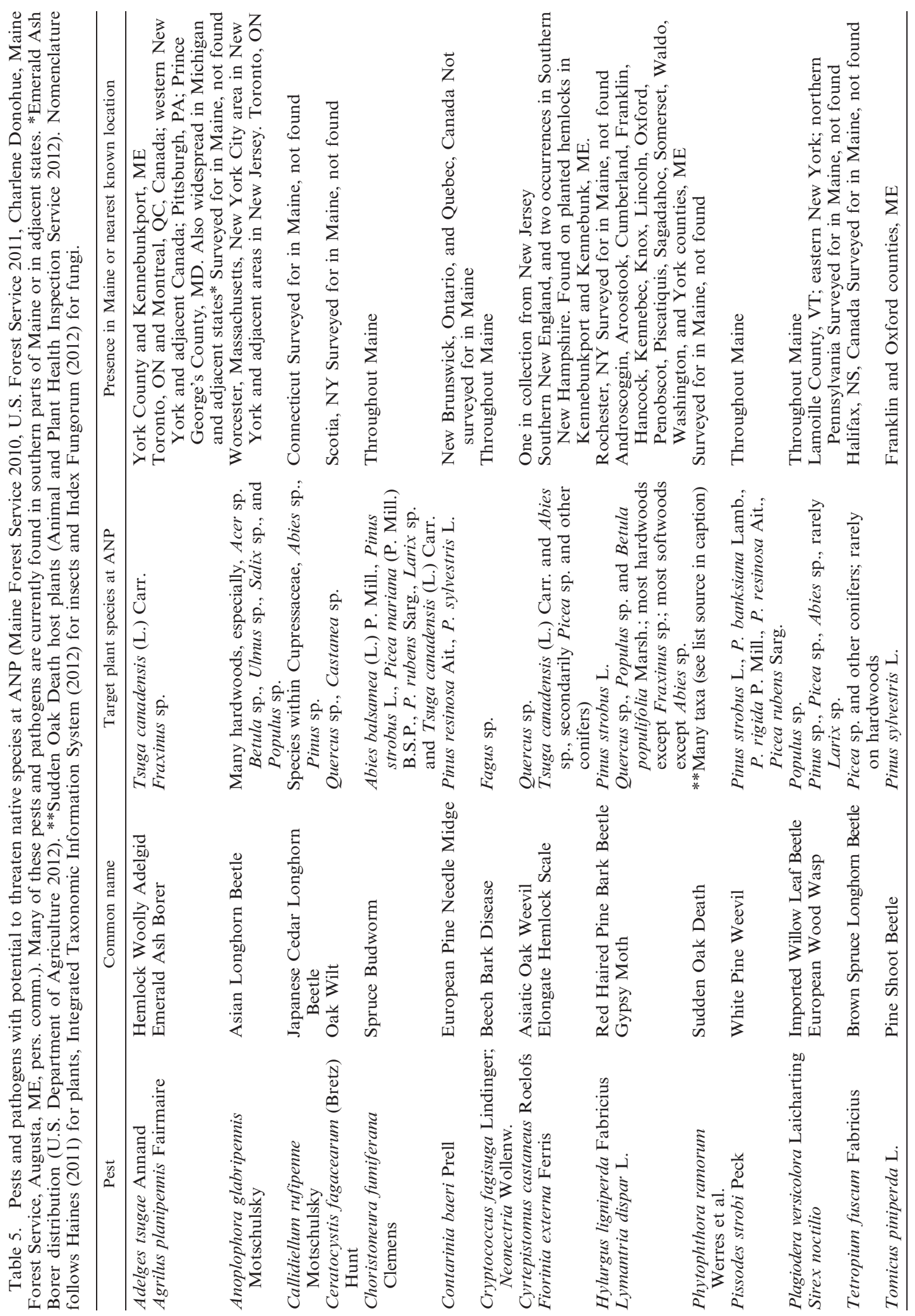


been reported in ANP, they have been documented from other areas in Maine or from nearby states throughout New England or the Toronto and Montréal areas of Canada (Lovett et al. 2006, Maine Forest Service 2005, Orwig et al. 2002, 2008, Small et al. 2005). Potentially affected species widespread at ANP include Tsuga Canadensis L. Carriere, Acer rubrum L., A. saccharum Marshall, Fraxinus americana L., and Quercus rubra L.

The unpredictability of new introductions of pests and pathogens combined with a lack of adequate knowledge of pests and pathogens currently threatening the flora of ANP limit our ability to forecast the nature and scope of change that could occur in ANP with the presence of one or more of these pests and pathogens. Data for these pests and pathogens are lacking or minimal for the three units of ANP. We were unable to find reports or publications for ANP dealing with the extent of distribution and damage for any of the pests or pathogens listed in Table 5, except for an unpublished draft report on common pests (Roberts and Dearborn 1999) and one outdated report on Beech Scale and Beech Bark Disease (Brower 1949).

Ozone. Ambient, ground-level ozone is a critical air pollutant influencing the health and productivity of eastern North American forests (Orendovici et al. 2003, Kohut 2007a, b, Kline et al. 2008). Acadia National Park experiences some of the highest concentrations of ozone in eastern North America (Davis 2007, Vaux et al. 2008). Due to the high ozone levels occurring there, ANP has been a center for ozone-related research (Bartholomay et al. 1997, Eckert et al. 1997, Kohut et al. 2000, Maniero and Breen 2004, Kohut 2007a, b). A study by Davis (2007) at Moosehorn National Wildlife Refuge in Maine (196 km northeast of ANP) documented a number of species exhibiting ozone-induced symptoms at atmospheric concentrations much lower than levels currently experienced in ANP (National Park Service 2010). This study suggests that plants at ANP are likely already affected by current ozone levels. At least twenty species in ANP have been identified as ozonesensitive (Table 6; Kohut et al. 2000, National Park Service 2003, 2004a, b).

Data on the impacts of ozone on terrestrial vegetation at ANP are primarily from sites on the eastern-facing side of MDI. Additional studies are needed from sites with other slopes,
Table 6. Ozone-sensitive species found in ANP. Species listed typically exhibit foliar injury at or near ambient ozone concentrations in fumigation chambers and/or have been confirmed as showing foliar injury symptoms in the field (National Park Service $2003,2004 \mathrm{a}, \mathrm{b})$. Taxa with $*$ are species recommended by Kohut et al. (2000) as those most suited as bioindicators of elevated ozone in ANP. Nomenclature follows Haines (2011).

\section{Species}

Apios americana Medik.

* Apocynum androsaemifolium L.

A. cannabinum $\mathrm{L}$.

Asclepias syriaca $\mathrm{L}$.

Clematis virginiana $\mathrm{L}$.

* Eurybia macrophylla (L.) Cass. (as Aster macrophyllus L.)

* Fraxinus americana L.

F. pennsylvanica Marsh.

Gaylussacia baccata (Wangenh.) K. Koch

Parthenocissus quinquefolia (L.) Planch.

Pinus banksiana Lamb.

$P$. rigida $\mathrm{P}$. Mill.

* Populus tremuloides Michx.

* Prunus serotina Ehrh.

$P$. virginiana $\mathrm{L}$.

Rubus allegheniensis Porter

$R$. canadensis $\mathrm{L}$.

Sambucus nigra subsp. canadensis (L.) R. Bolli (as S. canadensis L.)

Spartina alterniflora Loisel.

Symphoricarpos albus (L.) Blake

aspects, and elevations to determine whether they represent greater exposure to ozone (Haines and Webber 1999). More importantly, levels of ozone tolerance should be determined for a wider range of species at ANP, as ozoneinduced reductions in plant growth are likely to have lasting consequences on species composition and interactions in ANP.

Acidic Fog and Sulfur Deposition. Fog and cloud water contributes significant amounts of pollutants and nutrients to many ecosystems in eastern North America (Weathers et al. 1986, Schwartz 1989). Much of the vegetation in ANP is frequently exposed to acidic fog (Weathers et al. 1986). However, fog chemistry data for ANP have not been published since the 1980s (Andersen 1984, Weathers et al. 1986). Currently only a handful of studies have examined the influence of acidic fog on ANP's vegetation. Jagels et al. (2002) demonstrated differential sensitivity to acidic fog in Picea rubens Sarg. and Pinus strobus L., two common species at ANP. Pinus strobus shows sensitivity to ozone but not to acid fog (Kohut et al. 1990) whereas P. rubens is especially sensitive to acidic fog (Percy et al. 
1992). Differential sensitivity to pollutants among co-occurring taxa may influence stand level dynamics as well as regional plant community structure. Picea rubens, a regionally dominant species, is showing population declines in Maine, particularly at sites which receive both acidic fog and rain (Jiang and Jagels 1999). The greatest symptom development is in mid-coast Maine where ANP is located (Jagels et al. 1989).

Previous studies indicate that sulfate, nitrate, and ammonium are the dominant components of acidic fog in ANP (Weathers et al. 1986). A recent study on the air quality of National Parks in the U.S. reports higher than normal sulfur (S) levels for ANP with wet deposition rates of sulfate $>3 \mathrm{~kg} \mathrm{ha}^{-1} \mathrm{yr}^{-1}$ (National Park Service 2010). Weathers et al. (2006) reported modeled $\mathrm{S}$ deposition hotspots of up to $25 \mathrm{~kg} \mathrm{ha}^{-1} \mathrm{yr}^{-1}$, whereas at a reduced spatial scale, Nelson et al. (2007) found maxima of up to $13 \mathrm{~kg} \mathrm{ha}^{-1} \mathrm{yr}^{-1}$. Both datasets suggest relative hotspots of $\mathrm{S}$ deposition in conifer forests located in highelevation areas. Both studies demonstrate that $\mathrm{S}$ deposition and resulting acidity is a problem at ANP. Although S deposition has declined at ANP and across the northeast in response to decreased emissions due to the Clean Air Act (Kahl et al. 2004), current deposition rates are high enough to stress vegetation in ANP (National Park Service 2010).

More contemporary data are needed regarding the chemistry of acid fog and exposure levels throughout ANP. Additionally, data are needed on the sensitivity of individual species and sensitive communities to acidic fog (Hutchinson and Meema 1987, Turco 2002) and the effects of acid fog and sulfur deposition on $\mathrm{Al}^{3+}$ mobilization in water and soils (Munson and Gherini 1991, 1993) and on leaching of base cations from soils (Fernandez et al. 2003) at ANP. The acidity of other forms of precipitation such as rain and snow needs further investigation. Studies should also focus on combined effects of acid fog and ozone (Jagels et al. 2002, Lovett et al. 2009).

Nitrogen Deposition. In addition to its contribution to acidic fog, nitrogen (N) also contributes to nutrient enrichment in eastern North America and elsewhere (Lovett et al. 2009), leading to shifts in species composition (Gough et al. 2000) and $\mathrm{N}$ saturation which can result in a series of impacts on microbial and plant production and $\mathrm{N}$ cycling (Aber et al. 1998). A recent study on the air quality of National Parks in the U.S. reports higher than normal $\mathrm{N}$ deposition levels for ANP with wet deposition rates of $1-3 \mathrm{~kg} \mathrm{ha}^{-1} \mathrm{yr}^{-1}$ (National Park Service 2010). The report concludes that $\mathrm{N}$ deposition is of moderate concern with deposition via nitrate $\left(\mathrm{NO}_{3}{ }^{-}\right)$and ammonium $\left(\mathrm{NH}_{4}{ }^{+}\right)$being fairly stable in ANP and across the region (Kahl et al. 2004, Vaux et al. 2008).

Species adapted to low $\mathrm{N}$ may be sensitive to increased inputs of $\mathrm{N}$; bogs and fens are among the ecosystems at highest risk of shifts in species composition due to $\mathrm{N}$ deposition (Bobbink et al. 1998, Ellison and Gotelli 2002, Gotelli and Ellison 2006). Approximately six percent of ANP is covered by bog and boglike habitats (Karen Anderson, ANP, pers. comm.) and nitrogen deposition is likely already having a significant impact on bogassociated biota at ANP.

Impacts of nitrogen enrichment on ANP forests and aquatic plants need to be better documented and evaluated as increases in $\mathrm{N}$ are likely to cause significant species- and community-level changes throughout ANP (Vaux et al. 2008). There is also a need to examine the nature and effect of enrichment of other nutrients such as phosphorous (P), potassium $(\mathrm{K})$, and $\mathrm{S}$.

Mercury and Other Metals. Mid-coast Maine, where ANP is located, has been recognized as a hotspot for atmospheric mercury $(\mathrm{Hg})$ deposition and accumulation. The Park's location downwind of many $\mathrm{Hg}$ sources and its landscape characteristics enhance $\mathrm{Hg}$ deposition and retention as well as its transformation to methylmercury (Evers 2005, Sheehan et al. 2006, Bank et al. 2007, 2009, Johnson et al. 2007, Kahl et al. 2007, Nelson et al. 2008).

Studies examining effects of $\mathrm{Hg}$ on ecosystem processes in ANP have been conducted at long-term paired-watershed study sites (Bank et al. 2007, Kahl et al. 2007). Studies on the paired watersheds determined that vegetation type is a major influence of $\mathrm{Hg}$ levels in throughfall (Johnson et al. 2007, Nelson et al. 2008), litterfall (Sheehan et al. 2006), and soils (Amirbahman et al. 2004). Throughfall $\mathrm{Hg}$ flux from both rain and snow was greatest at conifer-dominated and mixed conifer-deciduous sites than at deciduous, shrub, or open sites (Johnson et al. 2007, Nelson et al. 2008). In soils, greater inorganic $\mathrm{Hg}$ was also found 
at conifer-dominated sites, but there was greater methylmercury in soils at hardwooddominated sites, which may reflect faster rates of microbial metabolism due to more rapid nutrient cycling and higher soil $\mathrm{pH}$ in the deciduous forest (Amirbahman et al. 2004).

Although the watersheds at ANP are among the most intensively studied for $\mathrm{Hg}$ in the world, the research has largely focused on how vegetation types influence $\mathrm{Hg}$ loads to the ecosystem. No studies have been conducted that characterize responses of plants to elevated levels of $\mathrm{Hg}$. Fog at ANP has never been studied for $\mathrm{Hg}$. Evidence from Nova Scotia indicates very high concentrations of $\mathrm{Hg}$ in fog on islands and along the coast relative to inland sites (Boudala et al. 2000, Vaux et al. 2008). The extent of fog-related $\mathrm{Hg}$ deposition to ANP's ecosystems is unknown.

Studies on other metals are less abundant. A study examining both $\mathrm{Hg}$ and $\mathrm{Pb}$ accumulation rates based on peat and sediment cores in a bog (Big Heath) and a pond (Sargent Mountain Pond), respectively, at ANP found that maximum accumulation rates for both $\mathrm{Hg}$ and $\mathrm{Pb}$ occurred in the 1970s and have decreased since then (Norton et al. 1997). Additional studies are needed with respect to $\mathrm{Al}$ (Decker and Boerner 1997, Lovett and Tear 2007) and other regionally abundant metals such as Copper $(\mathrm{Cu})$, Lead $(\mathrm{Pb})$, and Zinc $(\mathrm{Zn})$ (Rajakaruna et al. 2011).

FIRE. The importance of natural disturbances such as fire in shaping landscapes and influencing ecosystems is now well recognized in ecology (Abrams 1992, 1998, Turner et al. 1997, Foster et al. 1998, Bond et al. 2005). Stand-replacing, catastrophic fires have been rare at ANP. Patterson et al. (1983) list 10 major fires in the ANP region since the mid 1800s. The largest of these, the Fire of 1947, burned 6,875 ha and destroyed extensive stands of conifer forests on the eastern side of MDI and resulted in replacement with stands of Betula spp. and Populus spp. (Patterson et al. 1983). In addition to changes in vegetation and animal populations, the Fire of 1947 influenced soil structure and mercury dynamics (Kahl et al. 2007). Based on their examination of current stand age structure, standing and downed fuels, and charcoal in soils and fire scars on trees, Patterson et al. (1983) suggest that a 100-150 year fire rotation could be reasonable for ANP.
Prior to European settlement, fires lit by Native Americans were frequent (Patterson et al. 1983). In the post-settlement era, smoking, arson (in protest to federal policies), debris burning, and logging operations were common sources of fire; fires from lightning strikes were not common. Most recorded fires were human-caused and occurred during periods of peak visitor use (Sundays, particularly in July and August). The NPS has participated in some fire management at ANP; prescribed fire has been occasionally used to provide conditions necessary for fire-maintained communities (e.g., communities dominated by Pinus rigida Mill., Pinus banksiana Lamb, or Vaccinium species). Patterson et al. (1983) recommend fuel management in portions of the Park where accumulations are heavy due to blowdowns, increasing the risk of intense fires that could severely damage existing vegetation.

Patterson et al. (1983) classified forest stands at ANP into five fire-response groups (Patterson et al. 1983): Picea and Thuja stands in which the natural fire cycle is tied to the maturation cycle of the dominant trees; Pinus stands composed of fire-adapted species for which fire enhances the establishment of seedlings; Betula-Populus stands which often appear following fires that expose mineral soils; Quercus rubra stands which may benefit from moderate fires but are significantly affected by more intense fires; and Northern hardwood stands which are less likely to burn than other forest types but, when ignited, are also more susceptible to damage. They also classified the soils of ANP into four groups according to their susceptibility to fire damage (Patterson et al. 1983). More recently Devine et al. (2006) developed fire fuel load maps of ANP using data from the Acadia Vegetation Mapping Project (Lubinski et al. 2003) and field-collected fuel load data. Used with data on stand height, canopy cover, canopy bulk density, slope, aspect, and elevation, these fire fuel load data will enable future simulations of fire growth behavior. This is particularly important considering the accumulation of fuel in ANP due to the Park's policy regarding restricting the removal of dead wood.

The study by Patterson et al. (1983) serves as the only extensive treatment of the effects of fire on ANP's plants and ecosystems. Additional studies are needed to examine speciesand stand-level responses of vegetation in all plant community types at ANP and the 
potential for the use of prescribed burns to maintain fire-dependent communities and reduce fuel loads in the Park. The potential effects of climate change on fire frequency and intensity should also be assessed (Flannigan et al. 2000).

BRowsing. Damage caused to vegetation by browsing deer, hare, and other small mammals has not been well-documented in ANP. Historical, unpublished documents suggest that browsing pressure by deer was fairly high starting as early as the 1930s and continuing until the mid-1960s (Bruce Connery, ANP, pers. comm.). McLaughlin (1968) identified local areas of over-browsing, yet concluded that, overall, the flora of ANP was not over-browsed and that much of the browsing was limited to shrubs and trees. Gilbert and Harrison (1982a, b) examined the influence of white-tailed deer (Odocoileus virginianus Zimmermann), on vegetation of the MDI and IAH units of ANP and documented Acer rubrum and A. pensylvanicum, Betula spp., Ilex verticillata, Prunus spp., Quercus rubra, Rhus hirta, and Viburnum nudum var. cassinoides as the most heavilybrowsed species. They concluded that, with the exception of $R$. hirta, none of the species were browsed to a level which might restrict regeneration or cause deformation, defoliation, or mortality. Further, they suggested that no management efforts were needed and that monitoring should occur again in 10 years. Saeki (1991) concluded that browsing at MDI and IAH units of ANP has decreased since the surveys by Gilbert and Harrison (1982a, b). Although browsing appears not to pose a threat to ANP's flora, periodic monitoring should take place as recommended by Gilbert and Harrison (1982a, b).

Visitor Use. Acadia National Park is one of the most visited National Parks in the country (Manning et al. 2006). The summit loop trail at Cadillac Mountain, for example, is a major destination for visitors and receives an estimated $0.5-0.8$ million visitors during the summer (June-August) each year (Jacobi 2003). Hiking and trampling on trails and campsites results in loss of ground vegetation; altered vegetation composition, including introduction of non-native species; altered microclimate; soil compaction and erosion; loss of organic litter; and increased water runoff (Vaux et al. 2008). Greene et al. (2002) suggested that trampling by hikers is one of the primary stressors likely affecting rare plant species in ANP, and preventative measures should be developed and implemented for all trails with extensive visitor use. Kim and Daigle (2011) examined the efficacy of management strategies implemented in 2000 to reduce visitor-induced vegetation impact and enhance vegetation recovery at the summit loop trail on Cadillac Mountain. They concluded that, while management protocols have been effective in enhancing vegetation regeneration and reducing vegetation reduction, recovery has been rather minimal.

More data are needed to assess the direct (e.g., trampling) and indirect (e.g., increased vehicular exhaust) impacts of visitor use on rare species and sensitive communities at ANP, as well as on the Park's vegetation in general.

Hurricanes. Periodic natural events such as hurricanes represent an important natural disturbance in temperate forests in many coastal areas of the world, including on the north Atlantic coast where ANP is located (Neumann et al. 1987). There has been no research examining the effects of hurricane or hurricanelike disturbances at ANP. Although regional studies provide useful insight on hurricane induced changes in forest ecosystems (Carlton and Bazzaz 1998, Cooper-Ellis et al. 1999, Foster and Aber 2004), it will be critical to direct research in this area at ANP considering possible increases in hurricanes and other natural disturbances due to global climate change.

Synergistic Effects from Multiple StressORs. The synergistic effects of multiple stressors are a significant area of research that has been scarcely investigated at ANP. While individual stressors such as those we have described can cause significant threats to vegetation and ecosystems, it is the interaction among stressors that poses the most severe threats to biotic systems (Vinebrooke et al. 2004, Didham et al. 2005, Mothersill et al. 2007). The combined effects of ozone and acidic fog, for example, are of considerable concern in ANP (Lovett et al. 2009). The paired watershed system and longterm forest monitoring plots at ANP offer ideal conditions for monitoring the synergistic effects of these and other stressors in order to better manage ANP's flora.

Effects of Climate Change. Recent research in Maine has suggested a warming 
Table 7. Summary of stressors and threats to the flora of ANP and status of research at ANP (High, Moderate, and Minimal/Lacking) based on published and unpublished studies conducted at ANP in the last 20 to 30 years. Priority for research and management (High, Moderate, and Low) based on potential impact of stressors and threats on ANP's flora and their habitats identified from current literature and author expertise.

\begin{tabular}{lll}
\hline \multicolumn{1}{c}{ Stressor or threat } & \multicolumn{1}{c}{ Current park-specific research } & Research and management priority \\
\hline Invasive Plants & $\begin{array}{c}\text { MDI (Moderate); IAH \& SCH } \\
\text { (Minimal/Lacking) }\end{array}$ & High \\
Pests \& Pathogens & All Units (Minimal) & High \\
Ozone & MDI (Moderate); IAH \& SCH & Moderate \\
Acidic Fog and Sulfur Deposition & MDI (Moderate); IAH \& SCH & Moderate \\
Nitrogen Deposition & (Minimal/Lacking) & High \\
Mercury & All Units (Minimal/Lacking) & Low \\
& MDI (High); IAH \& SCH & \\
Other Heavy Metals/Road Salts & (Minimal/Lacking) & Low \\
Fire & All Units (Minimal/Lacking) & Moderate \\
Browsing & All Units (Minimal) & Low \\
Visitor Use & MDI (Moderate); IAH \& SCH & High \\
Hurricanes/Natural Disasters & (Minimal/Lacking) & Low \\
Synergistic Effects from Multiple & All Units (Minimal/Lacking) & High \\
Stressors & All Units (Minimal/Lacking) & High \\
Climate Change \& Associated & & \\
Impacts & & \\
\hline
\end{tabular}

trend and a decline in snowfall based on 50 years of climate and hydrologic data (Hodgkins et al. 2003, Huntington 2003, Huntington et al. 2004). There are no studies examining what effects climate change may have on ANP's flora. Because ANP is located in an ecotone between southern deciduous and northern coniferous forests, with many species occurring either at their most southern or most northern or eastern boundaries (Greene et al. 2005), species shifts as well as changes in phenology are likely to occur (Bertin 2008, Pompe et al. 2008, Thuiller et al. 2008). It is important to identify species and habitats in and around ANP which are likely to be most vulnerable to climate change. Species-level studies of ecological and evolutionary implications of climate change (Parmesan 2006) should be conducted to better inform management of range-restricted species found in aquatic and terrestrial habitats in and around ANP. In addition, more data is need on the synergistic effects of climate change and individual and multiple stressors as outlined in the preceding sections. We were also unable to find any research discussing the effects of current or potential sea level rise as a result of climate change; the impacts of sea level rise on the flora of ANP should be investigated, particularly given the Park's proximity to the ocean.
Recommendations for Future Research and Management. The flora of ANP has been well characterized (Greene et al. 2005, Mittlehauser et al. 2010) and the current stressors and imminent threats to the flora have largely been identified (Vaux et al. 2008). However, there is still much to be done to effectively address the stressors and threats impacting ANP's flora, especially with respect to the long-term effects of those stressors and their synergistic effects. Table 7 summarizes our knowledge of the current threats and stressors to ANP's flora and prioritizes the need for additional study and management.

Long-term forest plots are effective means to assess under-studied stressors and threats to ANP's flora, providing useful means to better understand forest processes and to develop sound management protocols at both the species and community levels (Bank et al. 2007, 2009, Lovett et al. 2007). Acadia National Park has several such long-term forest plots (National Park Service 2007b, Vaux et al. 2008), and these plots could be effectively utilized to generate stressor information that is currently minimal or lacking and to monitor how plant species respond to multiple stressors and threats over time. Without such long-term data, it is impossible to generate sound management plans for the conservation of species or the preservation of their habitats. 
In 1998, Park Research and Intensive Monitoring Ecosystems Network (PRIMENet) paired watersheds were established in ANP to examine long-term trends and linkages between environmental stressors and ecosystem responses (Tonnessen and Manski 2007). Protocols have also been developed for long-term monitoring of forest vegetation within the National Parks of the Northeast Temperate Network (NETN; National Park Service 2006, Tierney et al. 2009, Wang et al. 2009), including in ANP. The protocols include methods for assessing and reporting the ecological integrity of forested ecosystems throughout the northeast. The goal of such protocols is to effectively monitor the status and trends in the structure, function, and condition of NETN's forested ecosystems in order to inform management decisions affecting those ecosystems (National Park Service 2006, 2007b). Such a program, extended across multiple habitats and species assemblages across all three units of ANP could provide valuable information for understanding long-term forest dynamics in response to anthropogenic and naturally occurring stressors. Such information is critical in light of current predictions of the response of plants and ecosystems in northeastern North America to climate change (Bertin 2008, Campbell et al. 2009, Dukes et al. 2009, Groffman et al. 2009, Huntington et al. 2009). Given the high level of uncertainty associated with forecasting future climatic conditions and the ability to manage for region-specific goals, National Parks like ANP, should promote park-specific research and embrace adaptive resource management and scenario planning (Baron et al. 2009). However, to be able to do so effectively, it is critical that National Parks find ways to minimize institutional barriers to adaptive management (Jantarasami et al. 2010) and be willing to incorporate ecological thresholds, such as those outlined for air pollution (Fenn et al. 2011), when developing scientifically sound approaches to policy and management.

Effective approaches for restoring degraded plant populations in ANP also merit investigation and evaluation (D'Antonio and Meyerson 2002, Palmer et al. 2006), and candidate approaches need to be implemented and compared. Currently, such efforts are limited to a revegetation program initiated in 1994 (Chase and Gregory 2001, 2002, Gregory et al. 2002). Such programs should be incorporated in all affected areas within all units of ANP to restore and monitor areas already impacted by anthropogenic and natural stressors.

\section{Literature Cited}

Aber, J., W. McDowell, K. Nadelhoffer, A. Magill, G. Berntson, M. Kamakea, S. McNulty, W. Currie, L. Rustad, and I. FERNANDEZ. 1998. Nitrogen saturation in temperate forest ecosystems - Hypotheses revisited. BioScience 48: 921-934.

Abrams, M. D. 1992. Fire and the development of oak forests. BioScience 42: 346-353.

Abrams, M. D. 1998. The red maple paradox: What explains the widespread expansion of red maple in eastern forests? BioScience 48: 355-364.

Allen, B. 2005. Maine mosses: SphagnaceaeTimmiaceae. Mem. New York Botan. Gard. 93: $1-420$.

Allen, B. And R. A. Pursell. 2005. Maine Mosses. Fasciculus 6 (Nos. 301-325). Missouri Botanical Garden, St. Louis, MO.

Amirbahman, A., P. L. Ruck, I. J. Fernandez, T. A. Haines, And J. S. KaHL. 2004. The effect of fire on mercury cycling in the soils of forested watersheds: Acadia National Park, Maine, USA. Water Air Soil Poll. 152: 313-331.

Andersen, J. L. 1984. Potential impact of acid precipitation and poor air quality on the resources of Acadia National Park. National Park Service, North Atlantic Region, Office of Scientific Studies, OSS 85-1: 15-62.

Animal and Plant Health Inspection Service. 2012. APHIS list of regulated host plants proven or associated with Phytophora ramorum. Retrieved April 23, 2012 from U.S. Department of Agriculture. <www.aphis.usda.gov/plant_health/ plant_pest_info/pram/ $>$.

Bailo, B. G., M. R. C. Emison, W. B. Coleman, AND C. J. Burk. 2004. Thirty-six years of change in an eastern hemlock-white pine stand in western Massachusetts. Rhodora 106: 273-286.

BANK, M. S., J. Burgess, D. Evers, AND C. S. Loftin. 2007. Mercury contamination in biota from Acadia National Park, Maine, USA: A review. Environ. Monit. Assess. 126: 105-115.

BAnk, M. S., J. B. Crocker, S. DAvis, D. Brotherton, R. Cook, J. Behler, AND B. Connery. 2009. Population decline of Northern Dusky Salamanders at Acadia National Park, Maine, USA. Biol. Conserv. 130: 230-233.

Baron, J. S., L. Gunderson, C. D. Allen, E. Fleishman, D. McKenzie, L. A. Meyerson, J. Oropeza, and N. Stephenson. 2009. Options for National Parks and Reserves for adapting to climate change. Environ. Manage. 44: 10331042.

Bartholomay, G. A., R. T. Eckert, and K. T. SмiтH. 1997. Reductions in tree-ring widths of white pine following ozone exposure at Acadia National Park, Maine, USA. Can. J. For. Res. 27: 361-368.

Bennett, J. P. and C. M. Wetmore. 2005. Lichens of the U. S. National Parks. Bryologist 108: $544-553$. 
Bertin, R. I. 2008. Plant phenology and distribution in relation to recent climate change. J. Torrey Bot. Soc. 135: 126-146.

Bobbink, R., M. Hornung, and J. G. M. Roelofs. 1998. The effects of air-borne nitrogen pollutants on species diversity in natural and semi-natural European vegetation. J. Ecol. 86: 717-738.

Bond, W. J., F. I. Woodward, and G. F. Midgley. 2005. The global distribution of ecosystems in a world without fire. New Phytol. 165: 525-537.

Boudala, F. S., I. Folkins, S. Beauchamp, R. Tordon, J. Neima, And B. Johnson. 2000. Mercury flux measurements over air and water in Kejimkujik National Park, Nova Scotia. Water Air Soil Poll. 122: 183-202.

Breeuwer, A., M. Heijmans, B. J. M. Robroek, J. Limpens, And F. Berendse. 2008. The effect of increased temperature and nitrogen deposition on decomposition in bogs. Oikos 117: 1258-1268.

Brower, A. E. 1949. The beech scale and beech bark disease in Acadia National Park. J. Econ. Entomol. 42: 226-228.

Brumback, W. E., L. Merhoff, R. W. Enser, S. C. Gawler, R. G. Popp, P. Somers, D. D. Sperduto, W. D. Countryman, and C. B. Hellquist. 1996. Flora Conservanda: New England. The New England Plant Conservation Program (NEPCoP) list of plants in need of conservation. Rhodora 98: 233-361.

Campbell, C. S., H. P. Adams, P. Adams, A. C. Dibble, L. M. Eastman, S. C. Gawler, L. L. Gregory, B. A. Grunden, A. Haines, K. Jonson, S. C. RoOney, T. F. Vining, J. E. Weber, And W. A. Wright. 1995. Checklist of Vascular Plants of Maine, $3^{\text {rd }}$ Rev. Bull. 844, Maine Agricultural and Forest Experiment Station, Orono, ME.

Campbell, J. L., L. E. Rustad, E. W. Boyer, S. F. Christopher, C. T. Driscoll, I. J. Fernandez, P. M. Groffman, D. Houle, J. Kiekbusch, A. H. Magill, M. J. Mitchell, and S. V. Ollinger. 2009. Consequences of climate change for biogeochemical cycling in forests of northeastern North America. Can. J. Forest Res. 39: 264-284.

Carlton, G. C. and F. A. Bazzaz. 1998. Resource availability, heterogeneity, and congruence following simulated hurricane blowdown of a temperate forest. Ecology 79: 1305-1319.

Chase, G. E. And L. L. Gregory. 2001. Acadia National Park: Revegetation Program 2000 Annual Report. Acadia National Park Natural Resources Report 2001-07. Acadia National Park, Bar Harbor, ME.

Chase, G. E. And L. L. Gregory. 2002. Acadia National Park: Revegetation Program 2001 Annual Report. Acadia National Park Natural Resources Report 2002-06. Acadia National Park, Bar Harbor, ME.

Chase, G. E., L. L. Gregory, and J. Halperin. 2002. Acadia National Park Purple Loosestrife Management Program. 2001 Annual Summary. Acadia National Park Natural Resources Report 2002-01. Acadia National Park, Bar Harbor, ME.

Ciccotelli, B., T. B. Harris, B. Connery, and N. RAJAKARUNA. 2011. The vernal pool flora of
Acadia National Park, Mount Desert Island, Maine, USA. Rhodora 113: 260-279.

Cleavitt, N. L., A. C. Dibble, and D. A. Werier. 2009a. Influence of tree composition upon epiphytic macrolichens and bryophytes in old forests of Acadia National Park, Maine. Bryologist 112: 467-487.

Cleavitt, N. L., S. A. Williams, and N. G. Slack. 2009b. Relationship of bryophyte occurrence to rock type in upstate New York and Coastal Maine. Northeast. Nat. 16: 67-84.

Cooper-Ellis, S., D. R. Foster, G. Carlton, and A. LEZBERG. 1999. Forest response to catastrophic wind: results from an experimental hurricane. Ecology 80: 2683-2696.

Crow, G. E., W. D. Countryman, G. L. Church, L. M. Eastman, C. B. Hellquist, L. Merhoff, AND I. M. STORKS. 1981. Rare and endangered plant species in New England. Rhodora 83: 259-299.

Crum, H. A. And L. E. Anderson. 1981. Mosses of Eastern North America. 2 vols. Columbia University Press, New York, NY. 1330 p.

D’Antonio, C. And L. A. Meyerson. 2002. Exotic plant species as problems and solutions in ecological restoration: A synthesis. Restor. Ecol. 10: 703-713.

Davis, D. D. 2007. Ozone-induced symptoms on vegetation within the Moosehorn National Wildlife Refuge in Maine. Northeast. Nat. 14: 403-414.

Davis, R. B. 1964a. Bryophytes and lichens of the spruce-fir forests of the coast of Maine. I. The ground cover. Bryologist 67: 189-194.

Davis, R. B. 1964b. Bryophytes and lichens of the spruce-fir forests of the coast of Maine. II. The corticolous flora. Bryologist 67: 194-196.

Decker, K. L. and R. E. J. Boerner. 1997. Ca:Al ratio effects on growth and competitive interactions of northern red oak (Quercus rubra) and yellow poplar (Liriodendron tulipifera). J. Torrey Bot. Soc. 124: 286-296.

Devine, H. A., W. A. Millinor, and E. Eastman. 2006. Acadia National Park fire fuels database. Final Technical Report to National Park Service, Cooperative Agreement 4560C0027, Task Agreement 006. North Carolina State University, Raleigh, NC.

Didham, R. K., J. M. Tylianakis, M. A. Hutchison, R. M. Ewers, and N. J. Gemmell. 2005. Are invasive species the drivers of ecological change? Trends Ecol. Evol. 20: 470-474.

Dukes, J. S., J. Pontius, D. Orwig, J. R. Garnas, V. L. Rodgers, N. Brazee, B. Cooke, K. A. Theoharides, E. E. Stange, R. Harrington, J. Ehrenfeld, J. Gurevitch, M. Lerdau, K. Stinson, R. Wick, and M. Ayres. 2009. Responses of insect pests, pathogens, and invasive plant species to climate change in the forests of northeastern North America: What can we predict? Can. J. Forest Res. 39: 231-248.

Eckert, R., R. Kohut, T. Lee, and K. Stapelfeldt. 1997. Studies to assess the effects of ozone on native vegetation of Acadia National Park. 1996 Annual Report. University of New Hampshire and Boyce Thompson Institute for Plant Research, Ithaca, NY. 
Ellison, A. M. And N. J. Gotelli. 2002. Nitrogen availability alters the expression of carnivory in the northern pitcher plant, Sarracenia purpurea. Proc. Natl. Acad. Sci. USA 99: 4409-4412.

Evers, D. C. 2005. Mercury connections: The extent and effects of mercury pollution in northeastern North America. Biodiversity Research Institute, Gorham, ME.

Fenn, M. E., K. F. Lambert, T. F. Blett, D. A. Burns, L. H. Pardo, G. M. Lovett, R. A. Haeuber, D. C. Evers, C. T. Driscoll, And D. S. JefFries. 2011. Setting limits: Using air pollution thresholds to protect and restore U.S. Ecosystems. Issues In Ecology, Report Number 14. Ecological Society of America, Washington, D.C.

Fernandez, I. J., L. E. Rustad, S. A. Norton, J. S. Kahl, And B. J. Cosby. 2003. Experimental acidification causes soil base-cation depletion at the Bear Brook Watershed in Maine. Soil Sci. Soc. Am. J. 67: 1909-1919.

Flannigan, M. D., B. J. Stocks, and B. M. Wotton. 2000. Forest fires and climate change. Sci. Total Environ. 262: 221-230.

Foster, D. R., D. H. Knight, and J. F. Franklin. 1998. Landscape patterns and legacies resulting from large, infrequent forest disturbances. Ecosystems 1: 497-510.

Foster, D. R. And J. Aber [eds.]. 2004. Forests in Time: The Environmental Consequences of 1000 Years of Change in New England. Yale University Press, New Haven, CT. 496 p.

Gawler, S. C. 2000. Natural communities of Maine: Keys and descriptions. Maine Natural Areas Program, Augusta, ME.

Gawler, S. C. And A. Cutko. 2010. Natural Landscapes of Maine: A Guide to Natural Communities and Ecosystems. Maine Natural Areas Program, Augusta, ME. 296 p.

Gilbert, J. R. And J. A. HARrison. 1982a. Influence of white-tailed deer on vegetation of Mt. Desert Island, Acadia National Park. Report contract number CX1600-8-0045. U.S. Depart. Interior, National Park Service, North Atlantic Region.

Gilbert, J. R. and J. A. Harrison. 1982b. Influence of white-tailed deer on vegetation of Isle au Haut, Acadia National Park. Report contract number CX1600-8-0045. U.S. Depart. Interior, National Park Service, North Atlantic Region.

Gotelli, N. J. And A. M. Ellison. 2006. Forecasting extinction risk with non-stationary matrix models. Ecol. Appl. 16: 51-61.

Gough, L., C. W. OsenberG, K. L. Gross, and S. L. Collins. 2000. Fertilization effects on species density and primary productivity in herbaceous plant communities. Oikos 89: 428-39.

Greene, C. W., C. B. Hellquist, and L. L. GreGory. 1999. Survey of freshwater aquatic vegetation of Acadia National Park. Technical Report NPS/BSO-RNR/NRTR/00-3, U.S. Dept. Interior, National Park Service, Boston, MA.

Greene, C. W., J. E. Weber, and S. C. Rooney. 2002. Rare plant monitoring in Acadia National Park. Technical Report NPS/BSO-RNR/NRTR/ 2002-10, U.S. Dept. Interior, Acadia National Park, Boston Support Office.
Greene, C. W., J. E. Weber, S. C. Rooney, And K. B. Anderson. 2004. Invasive plant species distribution and abundance in Acadia National Park. Technical Report NPS/NER/NRTR 2004/003. Acadia National Park, Bar Harbor, ME.

Greene, C. W., L. L. Gregory, G. H. MittelhauSER, S. L. RoOney, AND J. E. Weber. 2005 Vascular flora of the Acadia National Park region, Maine. Rhodora 107: 117-185.

Greenwood, H. E. 1927a. A contribution to the cryptogamic flora of Mt. Desert. Maine Naturalist 7: 111-120.

Greenwood, H. E. 1927b. Two weeks at Echo Lake Camp, Mt. Desert Island, Maine. Bryologist 30: $112-114$

Gregory, L. L., G. E. Chase, and J. S. Wheeler. 2002. Acadia National Park: Revegetation program 2002 annual report. Acadia National Park Natural Resources Report 2002-08. Acadia National Park, Bar Harbor, ME.

Groffman, P. M., J. P. Hardy, M. C. Fisk, T. J. FAhey, AND C. T. Driscoll. 2009. Climate variation and soil carbon and nitrogen-cycling processes in a northern hardwood forest. Ecosystems 12: 927-943.

Haines, A. 2011. Flora Novae Angliae: A manual for the identification of native and naturalized higher vascular plants of New England. Yale University Press, New Haven, CT. 1008 p.

Haines, A. AND T. F. Vining. 1998. Flora of Maine. A manual for identification of native and naturalized vascular plants of Maine. V. F. Thomas and Co., Bar Harbor, ME. 847 p.

Haines, T. A. and H. M. Webber. 1999. An assessment of contaminant threats at Acadia National Park. Report submitted to National Park Service, Bar Harbor, ME.

Hinds, J. W. And P. L. Hinds. 2007. The macrolichens of New England. The New York Botanical Garden Press, New York, NY. 608 p.

Hodgkins, G., R. Dudley, and T. Huntington. 2003. Changes in the timing of high river flows in New England over the 20th century. J. Hydrol. 278: 244-252.

Huntington, T. G. 2003. Climate warming could reduce runoff significantly in New England. Agr. Forest Meteorol. 117: 193-201.

Huntington, T. G., G. Hodgkins, B. Keim, And R. Dudley. 2004. Changes in the proportion of precipitation occurring as snow in New England (1949-2000). J. Climate 17: 2626-2636.

Huntington, T. G., A. D. Richardson, K. J. McGuire, and K. Hayhoe. 2009. Climate and hydrological changes in the northeastern United States: Recent trends and implications for forested and aquatic ecosystems. Can. J. Forest Res. 39: 199-212.

Hutchinson, T. C. And K. M. Meema. 1987. Effects of atmospheric pollutants on forests, wetlands, and agricultural ecosystems. Springer-Verlag New York Inc., New York, NY. 652 p.

IndeX Fungorum. 2012. Index Fungorum. Retrieved from Index Fungorum Partnership April 20, 2012. <www.indexfungorum.org > .

InTEGRATED TAXONOMIC INFORMATION System. 2012 Integrated Taxonomic Information System. 
Retrieved from IT IS-North America April 20, 2012. <www.itis.gov>.

JACOBI, C. 2003. A census of vehicles and visitors to Cadillac Mountain, Acadia National Park, August 1, 2002. Acadia National Park Natural Resource Report 2002-05.

Jagels, R., J. Carlisle, R. Cunningham, S. Serreze, and P. Tsai. 1989. Impact of acid fog and ozone on coastal red spruce. Water Air Soil Poll. 48: 193-208.

Jagels, R., M. Jiang, S. Marden, and J. Carlisle. 2002. Red spruce canopy response to acid fog exposure. Atmos. Res. 64: 169-178.

Jantarasami, L. C., J. J. Lawler, And C. W. Thomas. 2010. Institutional barriers to climate change adaptation in U.S. National Parks and Forests. Ecol. Soc. 15: 33.

JIANG, M. AND R. JAGELS. 1999. Detection and quantification of changes in membrane-associated calcium in red spruce saplings exposed to acid fog. Tree Physiol. 19: 909-916.

Johnson, K. B., T. A. Haines, J. S. Kahl, S. A. Norton, A. Amirbahman, and K. D. Sheehan. 2007. Controls on mercury and methylmercury deposition for two watersheds in Acadia National Park, Maine. Environ. Monit. Assess. 126: 55-67.

Kahl, J. S., I. Fernandez, S. Norton, G. B. Wiersma, and G. Jacobson. 2003. Final integrated report: Establishing paired gauged watersheds at Acadia National Park for long-term research on acidic deposition, nitrogen saturation, forest health, and mercury biogeochemistry (1998-2002). University of Maine, Orono, ME.

Kahl, J. S., S. J. Nelson, J. L. Stoddard, S. A. Norton, And T. A. Haines. 2004. Lakewater chemistry at Acadia National Park, Maine, in response to declining acidic deposition, in protecting our diverse heritage: The role of parks, protected areas, and cultural sites, p. 314-321. In D. Harmon, B. M. Kilgore, and G. E. Vietzke [eds.], Proceedings of the George Wright Society/National Park Service Joint Conference, April 14-18, San Diego, CA. The George Wright Society, Hancock, MI.

Kahl, J. S., S. J. Nelson, I. Fernandez, T. Haines, S. Norton, G. B. Wiersma, G. Jacobson, A. Amirbahman, K. Johnson, M. Schauffler, L. Rustad, K. Tonnessen, R. Lent, M. Bank, J. Elvir, J. Eckhoff, H. Caron, P. Ruck, J. Parker, J. Campbell, D. Manski, R. Breen, K. Sheehan, and A. Grygo. 2007. Watershed nitrogen and mercury geochemical fluxes integrate landscape factors in long-term research watersheds at Acadia National Park, Maine, USA. Environ. Monit. Assess. 126: 9-25.

Kim, M. AND J. J. DAIGle. 2011. Detecting vegetation cover change on the summit of Cadillac Mountain using multi-temporal remote sensing datasets: 1979, 2001, and 2007. Environ. Monit. Assess. 180: 63-75.

Kline, L. J., D. D. Davis, J. M. Skelly, J. E. Savage, and J. Ferdinand. 2008. Ozone sensitivity of 28 plant sections exposed to ozone under controlled conditions. Northeast. Nat. 15: 57-66.

Kohut, R. J. 2007a. Ozone risk assessment for Vital Signs Monitoring Networks, Appalachian
National Scenic Trail, and Natchez Trace National Scenic Trail. NPS/NRPC/ARD/NRTR2007/001. National Park Service, Fort Collins, $\mathrm{CO}$.

Kohut, R. J. 2007b. Assessing the risk of foliar injury from ozone on vegetation in parks in the U.S. National Park Service's Vital Signs Network. Environ. Poll. 149: 348-357.

Kohut, R. J., J. A. Laurence, R. G. Amundson, R. M. RabaAnd, and J. J. Melkonian. 1990. Effects of ozone and acidic precipitation on the growth and photosynthesis of red spruce after two years exposure. Water Air Soil Poll. 51: 277-286.

Kohut, R. J., J. A. Laurence, P. King, And R. RABA. 2000. Identification of bioindicator species for ozone and assessment of the responses to ozone of native vegetation at Acadia National Park. Technical Report NPS/BSO-RNR/NRTR/ 00-13. U.S. Dept. Interior, National Park Service, Boston, MA.

Lovett, G. M., C. D. Canham, M. A. Arthur, K. C. Weathers, and R. D. Fitzhugh. 2006. Forest ecosystem responses to exotic pests and pathogens in eastern North America. BioScience 56: $395-405$.

Lovett, G. M. And T. H. Tear. 2007. Effects of atmospheric deposition on biological diversity in the eastern United States. Report published by The Institute of Ecosystem Studies and the Nature Conservancy, Albany, NY.

Lovett, G. M., D. A. Burns, C. T. Driscoll, J. C. Jenkins, M. J. Mitchell, L. Rustad, J. B. Shanley, G. E. Likens, and R. Haeuber. 2007. Who needs environmental monitoring? Front. Ecol. Environ. 5: 253-260.

Lovett, G. M., T. H. Tear, D. C. Evers, S. E. G. Findlay, B. J. Cosby, J. K. Dunscomb, C. T. Driscoll, and K. C. Weathers. 2009. Effects of air pollution on ecosystems and biological diversity in the eastern United States. Ann. NY Acad. Sci. 1162: 99-135.

Lubinski, S., K. Hopp, and S. Gawler. 2003. U.S. Geological Survey - National Park Service vegetation mapping program. Acadia National Park. Retrieved January 3, 2010 from U.S. Geological Survey, Upper Midwest Environmental Sciences Center, La Crosse, Wisconsin. $<$ http://biology.usgs.gov/npsveg/acad/acadrpt.pdf $>$.

Maine Department of Environmental ProtecTION. 2005. Invasive aquatic plants. Retrieved November 11, 2011 from Maine Department of Environmental Protection. <http://www.maine. gov/dep/blwq/topic/invasives/index.htm $>$.

Maine Forest Service. 2005. Invasive threats to Maine's forests and trees. Retrieved February 20, 2010 from Department of Conservation, Augusta, ME. <http://www.maine.gov/doc/mfs/ InvasiveThreats.htm $>$.

Maine Forest Service. 2010. Invasive threats to Maine's forests and trees. Retrieved from Maine Forest Service May 4, 2010. < http://www.maine. gov/doc/mfs/InvasiveThreats.htm\#EAB $>$.

Maine Natural Areas Program. 2005a. Maine rare plant list and rare plant fact sheets. Retrieved February 19, 2010 from Department of Conservation, Augusta, ME. <http://www. maine.gov/doc/nrimc/mnap/features/plantlist.htm $>$. 
Maine Natural Areas Program. 2005b. Invasive plants fact sheets. Retrieved February 19, 2010 from Department of Conservation, Augusta, ME. <http://www.maine.gov/doc/nrimc/mnap/ features/invsheets.htm $>$.

Maine Natural Areas Program. 2005c. Natural community fact sheets. Retrieved November 11 , 2011 from Department of Conservation, Augusta, ME. < http://www.maine.gov/doc/nrimc/ mnap/features/commsheets.htm $>$

Maniero, T. And B. Breen. 2004. Acadia National Park: Assessment of long-term air quality programmatic, monitoring and research needs. National Park Service, Acadia National Park, Bar Harbor, ME.

Manning, R., C. Jacobi, And J. L. Marion. 2006. Recreation monitoring at Acadia National Park. The George Wright Forum 23: 59-72.

McLaughlin, F. L. 1968. Ecological relationships of white-tailed deer and vegetation at Acadia National Park. M.S. Thesis. University of Maine, Orono, ME.

Miller, N. G. 2006. Maine Mosses: SphagnaceaeTimmiaceae. Rhodora 108: 184-187.

Mittelhauser, G. H., J. Hazen-Connery, and J. JACOBS. 1996. Inventories of selected flora and fauna on 10 islands of Acadia National Park, Maine. Natural Resources Technical Report NPS/NESO-RNR/NRTR/96-01, National Park Service, New England System Support Office, Boston, MA.

Mittelhauser, G. H., L. L. Gregory, S. C. Rooney, J. E. Weber, M. Lovit, And D. Kausen. 2010. Field guide to the plants of Acadia National Park. Univ. Maine Press, Orono, ME. 248 p.

Mothersill, C., I. Mosse, and C. Seymour [eds.]. 2007. Multiple stressors: A challenge for the future. NATO science for peace and security series C: Environmental security. Springer, Dordrecht, The Netherlands. 504 p.

Munson, R. K. And S. A. Gherini. 1991. Hydrochemical assessment methods for analyzing the effects of acidic deposition on surface waters, p. 35-64. In D. F. Charles [ed.], Acidic deposition and aquatic ecosystems: Regional case studies. Springer-Verlag, New York, NY.

Munson, R. K. And S. Gherini. 1993. Influence of organic acids on the $\mathrm{pH}$ and acid-neutralizing capacity of Adirondack lakes. Water Resour. Res. 29: 891-899.

National Park Service. 2003. Ozone sensitive plant species on National Park Service and U.S. Fish and Wildlife Service Lands: Results of a June 2425, 2003 Workshop in Baltimore, Maryland. National Park Service Air Resources Division and U.S. Fish and Wildlife Service Air Quality Branch. NPS D1522 Natural Resource Report NPS/NRARD/NRR-2003/01. Retrieved May 2, 2010 from National Park Service. <http://www. nature.nps.gov/air/Pubs/pdf/BaltFinalReport1.pdf $>$.

National Park Service. 2004a. Ozone sensitive plant species, by park. Retrieved May 2, 2010 from National Park Service. <http://www.nature. nps.gov/air/permits/aris/docs/Ozone_Sensitive_ ByPark_3600.pdf $>$.
National Park Service. 2004b. Assessing the risk of foliar injury from ozone on vegetation in parks in the Northeast Temperate Network. Retrieved May 2, 2010 from National Park Service. $<$ http://www.nature.nps.gov/air/Pubs/pdf/03Risk/ netnO3RiskOct04.pdf $>$.

National Park Service. 2006. Northeast Temperate Network Vital Signs Monitoring Plan Technical Report NPS/NER/NRTR-2006/059. Retrieved January 02, 2010 from National Park Service. <http://science.nature.nps.gov/im/units/ NETN/downloads/NETN_MonitoringPlan_ VitalSign_Compress.pdf $>$.

National Park Service. 2007a. Appendix: invasive plant species known to occur within and in close proximity to northeast temperate network parks. Retrieved January 02, 2010 from National Park Service. <http://science.nature.nps.gov/im/units/ netn/downloads/phase3/appendix_invasive_plants. pdf $>$.

National Park Service. 2007b. Inventory and monitoring program. Reports and publications. Retrieved January 02, 2010 from National Park Service. <http://science.nature.nps.gov/im/units/ NETN/Reports/reports.cfm\#protocolDS $>$.

National Park Service. 2010. Air quality in national parks: 2009 annual performance and progress report. Natural Resource Report NPS/ NRPC/ARD/NRR_-2010/266. Air Resources Division, National Park Service, Denver, CO.

Neckles, H., A. Gilbert, G. Guntenspergen, N. Danz, T. Hollenhorst, A. Little, and J. OLKER. 2007. Protocol for monitoring freshwater wetlands in National Parks of the Northeast Temperate Network. Draft Report. U.S. Dept. Interior and U.S. Geological Survey, Reston, VA.

Nelson, S. J., J. S. Kahl, I. J. Fernandez, K. D. Sheehan, A. Grygo Diamond, K. B. Johnson, AND K. C. Weathers. 2007. Final Report: Understanding atmospheric deposition to complex landscapes at Acadia National Park, Maine, 2002-2005. National Park Service, Northeast Region, Technical Report NPS/NER/NRTR2007/080.

Nelson, S. J., K. B. Johnson, K. C. Weathers, C. S. Loftin, I. J. Fernandez, J. S. Kahl, and D. P. Krabbenhoft. 2008. A comparison of winter mercury accumulation at forested and no-canopy sites measured with different snow sampling techniques. Appl. Geochem. 23: 384-398.

Neumann, C. J., B. R. Jarvinen, A. C. Pike, And J. D. Elms. 1987. Tropical cyclones of the north Atlantic Ocean, 1871-1986. National Climatic Data Center in cooperation with the National Hurricane Center, Coral Gables, FL.

New England Wildflower Society. 2010. Rare plants and conservation. Retrieved from New England Wildflower Society January 1, 2010. $<$ http://www.newfs.org/protect/rare-plants-andconservation $>$.

Norton, S. A., G. C. Evans, and J. S. Kahl. 1997. Comparison of $\mathrm{Hg}$ and $\mathrm{Pb}$ fluxes to hummocks and hollows of ombrotrophic big heath bog and to nearby Sargent Mt. pond, Maine, USA. Water Air Soil Poll. 100: 271-286. 
Orendovici, T., J. M. Skelly, J. A. Ferdinand, J. E. Savage, M. -J. Sanz, and G. C. Smith. 2003. Response of native plants of northeastern United States and southern Spain to ozone exposures: Determining exposure/response relationships. Environ. Pollut. 125: 31-40.

Orwig, D. A., D. R. Foster, and D. L. Mausel. 2002. Landscape patterns of hemlock decline in New England due to the introduced Hemlock Wooly Adelgid. J. Biogeogr. 29: 1475-1487.

Orwig, D. A., R. C. Совв, A. W. D’Amato, M. L. Kizlinski, And D. R. Foster. 2008. Multi-year ecosystem response to hemlock woolly adelgid infestation in southern New England forests. Can. J. Forest Res. 38: 834-843.

Palmer, M. A., D. A. FAlk, And J. B. Zedler [eds.]. 2004. Foundations of restoration ecology. Island Press, Washington, D.C. 384 p.

Parmesan, C. 2006. Ecological and evolutionary responses to recent climate change. Annu. Rev. Ecol. Evol. S. 37: 637-669.

Patra, M. And A. Sharma. 2000. Mercury toxicity in plants. Bot. Rev. 66: 379-422.

Patterson, P. M. 1930. The mosses of Mount Desert Island, Maine. Bryologist 33: 83-89.

Patterson, W. A., K. E. Saunders, and L. J. Horton. 1983. Fire regimes of the coastal Maine forests of Acadia National Park. Publication OSS 83-3, U.S. Dept. Interior, National Park Service, Boston, MA.

Percy, K. E., K. F. Jenen, and C. J. McQuattie. 1992. Effects of ozone and acidic fog on red spruce needle epicuticular wax production, chemical composition, cuticular membrane ultrastructure and needle wettability. New Phytol. 122: 71-80.

Pompe, S., J. Hanspach, F. Badeck, S. Klotz, W. Thuiller, And I. KüHn. 2008. Climate and land use change impacts on plant distributions in Germany. Biol. Lett. 4: 564-567.

Rajakaruna, N., T. B. Harris, S. Clayden, A. Dibble, and F. C. Olday. 2011. Lichens of Callahan Mine, a copper- and zinc-enriched Superfund site in Brooksville, Maine, USA. Rhodora 113: 1-31.

RAND, E. L. AND J. H. Redfield. 1894. Flora of Mount Desert Island, Maine: A preliminary catalogue of the plants growing on Mount Desert and the adjacent Islands. Cambridge University Press, Cambridge, MA. 302 p.

Reiner, D. And T. McLendon. 2002. Assessment of exotic plant species of Acadia National Park. Evaluation of potential impacts of known exotic plants and summary of management options for species of concern. Technical Report NPS/ BSO-RNR/NRTR/2002-5. U.S. Dept. Interior, National Park Service, Boston Support Office, Boston, MA.

Roberts, V. A. And R. G. Dearborn. 1999. Light trapping as a measure of diversity and to monitor pest species in Acadia National Park, Bar Harbor, ME. Unpublished Report ACAD 1998 submitted to Acadia National Park, Bar Harbor, ME.

SAEKI, M. 1991. Influence of browsing by whitetailed deer and snowshoe hare on vegetation at
Acadia National Park, Maine. M.S. Thesis. University of Maine, Orono, ME.

Schnooberger, I. AND F. Wynne. 1941. Some mosses new to Mount Desert Island and Maine. Bryologist 44: 102-103.

Schwartz, S. E. 1989. Acid deposition: Unraveling a regional phenomenon. Science 243: 753-763.

Selva, S. B. 1994. Lichen diversity and stand continuity in the northern hardwoods and spruce-fir forests of northern New England and western New Brunswick. Bryologist 97: 424-429.

Senter, J. 1985. An initial inventory of the bryophytes of Mt. Desert Island, Hancock County, Maine. Senior Thesis. College of the Atlantic, Bar Harbor, ME.

Sheehan, K. D., I. J. Fernandez, J. S. Kahl, and A. Amirbahman. 2006. Litterfall mercury in two forested watersheds at Acadia National Park, Maine, USA. Water Air Soil Poll. 170: 249-265.

Small, M. J., C. J. Small, and G. D. Dreyer. 2005. Changes in a hemlock-dominated forest following wooly adelgid infestation in southern New England. J. Torrey Bot. Soc. 132: 458-470.

Stebbins, G. L., JR. 1929. Further additions to the Mt. Desert Flora. Rhodora 31: 81-87.

Sullivan, T. J. 1996. The lichens of Acadia National Park, Maine. Ph.D. dissertation, University of Minnesota, Minneapolis, MN.

Thuiller, W., C. Albert, M. B. Araújo, P. M. Berry, M. Cabeza, A. Guisan, T. Hickler, G. F. Midgley, J. Paterson, F. M. Schurr, M. T. Sykes, and N. E. Zimmermann. 2008. Predicting global change impacts on plant species' distributions: Future challenges. Perspect. Plant Ecol. 9: 137-152.

Tierney, J. L., D. Faber-Langendoen, B. R. Mitchell, W. G. Shriver, and J. P. Gibbs. 2009. Monitoring and evaluating the ecological integrity of forest ecosystems. Front. Ecol. Environ. 7: 308-316

Tonnessen, K. And D. Manski. 2007. The contribution of Acadia PRIMENet research to science and resource management in the National Park Service. Environ. Monit. Assess. 126: 3-8.

Torchin, M. E. And C. E. Mitchell. 2004. Parasites, pathogens, and invasions by plants and animals. Front. Ecol. Environ. 2: 183-190.

Turco, R. P. 2002. Earth under siege: From air pollution to global change, $2^{\text {nd }}$ edition. Oxford University Press, New York, NY. 552 p.

Turner, M. G., V. H. Dale, and E. H. Everham, III. 1997. Fires, hurricanes, and volcanoes: Comparing large disturbances. BioScience 47: 758-768.

U.S. Department of Agriculture. 2012. Cooperative Emerald Ash Borer Project. In collaboration with Michigan State University, Purdue University, and Ohio State University. Retrieved April 14, 2012 from Michigan State University. <http://www.emeraldashborer.info/files/ MultiState_EABpos.pdf $>$.

U.S. Forest SERVICE. 2011. Northeastern area. Forest and tree health publications. Retrieved November 11, 2011 from U.S. Forest Service. $<$ http://www.na.fs.fed.us/pubs/palerts.shtm $>$.

van der Putten, W. H., J. N. Klironomos, and D. A. WARdLE. 2007. Microbial ecology of biological invasions. ISME J. 1: 28-37. 
Vaux, P. D., S. J. Nelson, N. Rajakaruna, G. Mittelhauser, K. Bell, B. Kopp, J. Peckenham, AND G. LONGSwOrth. 2008. Assessment of natural resources and watershed conditions in and adjacent to Acadia National Park. Natural Resource Technical Report NPS/HTLN/ NRTR - 2006/001. National Park Service, Fort Collins, Colorado, USA.

Vinebrooke, R. D., K. L. Cottingham, J. Norberg, M. Scheffer, S. I. Dodson, S. C. Maberly, and U. Sommer. 2004. Impacts of multiple stressors on biodiversity and ecosystem functioning: The role of species co-tolerance. Oikos 104: 451-457.

WANG, Y., B. R. Mitchell, J. Nugranad-Marzilli, G. Bonynge, Y. Zhou, and G. Shriver. 2009. Remote sensing of land-cover change and landscape context of the National Parks: A case study of the Northeast Temperate Network. Remote Sens. Environ. 113: 1453-1461.
Weathers, K. C., G. E. Likens, F. H. Bormann, J. S. Eaton, W. B. Bowden, J. L. Andersen, D. A. Cass, J. N. Galloway, W. C. Keene, K. D. Kimball, P. Huth, and D. Smiley. 1986. A regional acidic cloud/fog water event in the eastern United States. Nature 319: 657-658.

Weathers, K. C., S. M. Simkin, G. M. Lovett, and S. E. LindBerG. 2006. Empirical modeling of atmospheric deposition in mountainous landscapes. Ecol. Appl. 16: 1590-1607.

Weber, J. E. And S. C. Rooney. 2007. Management plans for invasive plant species of Acadia National Park. Natural Resources Report NPS/NER/NRR2007/018. National Park Service, Boston, MA.

Wetmore, C. M. 1984. Lichens and air quality in Acadia National Park. National Park Service Contract CX 0001-2-0034. National Park Service, Denver, CO.

Wherry, E. T. 1928. Wild Flowers of Mount Desert Island, Maine. Lancaster Press, Lancaster, PA. 164 p. 